\title{
New national and regional bryophyte records, 55
}

\author{
L. T. Ellis, O. M. Afonina, M. Aleffi, R. L. Andriamiarisoa, M. Bačkor, M. Goga,
} H. Bednarek-Ochyra, D. A. Callaghan, P. Campisi, M. G. Dia, M. L. Marino, J. Enroth, P. Erzberger, V. Hugonnot, E. A. Ignatova, T. Kiebacher, J. Kučera, M. Lebouvier, G. M. Maria, S. Ştefănuţ, J. Nagy, T. Pócs, S. Poponessi, R. Venanzoni, D. Gigante, F. Prosser, C. Reeb, M. S. Sabovljević, J. R. Shevock, S. Shirzadian, S. Akhoondi Darzikolaei, E. R. F. Souza, A. Silva Pinto, J. B. Silva, S. F. Lopes, K. Torzewski \& A. Kazienko

To cite this article: L. T. Ellis, O. M. Afonina, M. Aleffi, R. L. Andriamiarisoa, M. Bačkor, M. Goga, H. Bednarek-Ochyra, D. A. Callaghan, P. Campisi, M. G. Dia, M. L. Marino, J. Enroth, P. Erzberger, V. Hugonnot, E. A. Ignatova, T. Kiebacher, J. Kučera, M. Lebouvier, G. M. Maria, S. Ștefănuț, J. Nagy, T. Pócs, S. Poponessi, R. Venanzoni, D. Gigante, F. Prosser, C. Reeb, M. S. Sabovljević, J. R. Shevock, S. Shirzadian, S. Akhoondi Darzikolaei, E. R. F. Souza, A. Silva Pinto, J. B. Silva, S. F. Lopes, K. Torzewski \& A. Kazienko (2018): New national and regional bryophyte records, 55, Journal of Bryology, DOI: 10.1080/03736687.2018.1454161

To link to this article: https://doi.org/10.1080/03736687.2018.1454161

\section{Published online: 27 Apr 2018.}

Џ Article views: 24
Submit your article to this journal $\sqsubset$ 

records, 55

\author{
L. T. Ellis ${ }^{1}$, O. M. Afonina ${ }^{2}$, M. Aleffi ${ }^{3}$, R. L. Andriamiarisoa ${ }^{4}$, M. Bačkor ${ }^{5}$, \\ M. Goga ${ }^{5}$, H. Bednarek-Ochyra ${ }^{6}$, D. A. Callaghan7, P. Campisi ${ }^{8}$, M. G. Dia ${ }^{8}$, \\ M. L. Marino ${ }^{8}$, J. Enroth ${ }^{9}$, P. Erzberger ${ }^{10}$, V. Hugonnot $^{11}$, E. A. Ignatova ${ }^{12}$, \\ T. Kiebacher ${ }^{13}$, J. Kučera ${ }^{14}$, M. Lebouvier $^{15}$, G. M. Maria ${ }^{16}$, S. Ştefănuţ ${ }^{16}$, \\ J. Nagy ${ }^{17}$, T. Pócs ${ }^{18}$, S. Poponessi ${ }^{19}$, R. Venanzoni ${ }^{19}$, D. Gigante ${ }^{19}$, F. Prosser ${ }^{20}$, \\ C. Reeb $^{21}$, M. S. Sabovljević ${ }^{22}$, J. R. Shevock ${ }^{23}$, S. Shirzadian ${ }^{24}$, S. Akhoondi \\ Darzikolaei $^{24}$, E. R. F. Souza ${ }^{25}$, A. Silva Pinto ${ }^{25}$, J. B. Silva ${ }^{25}$, S. F. Lopes ${ }^{25}$, \\ K. Torzewski ${ }^{26}$, A. Kazienko ${ }^{26}$
}

${ }^{1}$ The Natural History Museum, London, UK, ${ }^{2}$ Russian Academy of Sciences, Komarov Botanical Institute, Moscow, Russia, ${ }^{3}$ University of Camerino, Camerino, MC, Italy, ${ }^{4}$ Missouri Botanical Garden, Antananarivo, Madagascar, ${ }^{5}$ Institute of Biology and Ecology, Pavol Jozef Šafárik University, Košice, Slovakia, ${ }^{6}$ Polish Academy of Sciences, W. Szafer Institute of Botany, Kraków, Poland, ${ }^{7}$ Bryophyte Surveys Ltd, Stroud, Gloucestershire, UK, ${ }^{8}$ University of Palermo, Palermo, Italy, ${ }^{9}$ Department of Biosciences and Botanical Museum, University of Helsinki, Helsinki, Finland, ${ }^{10}$ Berlin, Germany, ${ }^{11}$ Conservatoire Botanique National du Massif Central, Chavaniac Lafayette, France, ${ }^{12}$ Lomonosov Moscow State University, Moscow, Russia, ${ }^{13}$ University of Zürich, Zürich, Switzerland, ${ }^{14}$ University of South Bohemia, České Budějovice, Czech Republic, ${ }^{15}$ CNRS UMR 6553, Université de Rennes 1, Paimpont, France, ${ }^{16}$ Institute of Biology Bucharest of Romanian Academy, Bucharest, Romania, ${ }^{17}$ Szent István University, Budapest, Hungary, ${ }^{18}$ Eszterházy College, Eger, Hungary, ${ }^{19}$ University of Perugia, Perugia, Italy, ${ }^{20}$ Botanical section, Civic Museum of Rovereto, Italy, ${ }^{21}$ Institut de Systématique, Évolution, Biodiversité, Muséum National d'Histoire Naturelle, Sorbonne Universités, Paris, France, ${ }^{22}$ Institute of Botany and Botanical Garden, University of Belgrade, Belgrade, Serbia, ${ }^{23}$ California Academy of Sciences (CAS), USA, ${ }^{24}$ Iranian Research Institute of Plant Protection, Agricultural Research Education and Extension Organization (AREEO), Tehran, Iran, ${ }^{25}$ State University of Paraíba, Campina Grande PB, Brazil, ${ }^{26}$ University of Wroclaw, Wroctaw, Poland.

\section{Acroschisma wilsonii (Hook.f.) A.Jaeger Contributor: H. Bednarek-Ochyra}

Venezuela: (1) Mérida, Páramo de Mucubají, vertiente de la Laguna de los Patos, Sierra de Santo Domingo, sobre roca ígnea, $3690 \mathrm{~m}$ a.s.l., Julio 1972, leg. D. Griffin III 944 (B, KRAM); (2) Mérida, Pico del Áquila, Sierra de Santo Domingo, sobre roca, $3800 \mathrm{~m}$ a.s.l., Agosto 1972, leg. D. Griffin III 1317 (B, KRAM).

Acroschisma wilsonii is endemic to South America, with its main centre of occurrence in the cool-temperate zone (Greene, 1986). It was erroneously recorded from China (Redfearn \& Wu, 1986) and regrettably, this Chinese occurrence is continuously indicated in the Tropicos database (http://tropicos.org/Name/ 35108242?tab=distribution). Likewise, in the same

Correspondence to: L. T. Ellis. Department of Life Sciences, The Natura History Museum, Cromwell Road, London SW7 5BD, UK Email: I.ellis@ nhm.ac.uk database the type of Andreaea wilsonii Hook.f., the basionym of Acroschisma wilsonii, is shown to have been collected 'In insulis Aucklandi et Campbelli' south of New Zealand, whilst in fact this species was described from the specimen collected in Hermite Island at Cape Horn (Hooker \& Wilson, 1844) and has never been recorded in Australasia. The species is characterised by having long cylindrical capsules dehiscing by $4-8$ slits confined to near the apex and the lines of dehiscence form tooth-like processes which are not united at the tips. This is a unique feature of Andreaea wilsonii and therefore this species was placed in the separate subgenus Andreaea Hedw. subg. Acroschisma Hook.f. \& Wilson (Hooker \& Wilson, 1844) which was soon raised to the separate genus Acroschisma (Hook.f. \& Wilson) Lindl. (Lindley, 1846).

Acroschisma wilsonii has its main centre of occurrence in the Tierra del Fuego archipelago and in 
southern and western Patagonia, extending northwards to the XIV Los Ríos Région in Chile at lat. $c a$ 39 $30^{\prime} \mathrm{W}$ (Müller, 2009). Then, the species recurs in the northern Andes of Ecuador and Colombia, where is occurs at high elevations of $3385-4100 \mathrm{~m}$ and 3040-3750 $\mathrm{m}$ a.s.1., respectively (Churchill et al., 2000). It was also reported from Peru (Soukup, 1951) but this record has never been confirmed. Herein, the species is recorded for the first time from Venezuela where it was found at two sites in the Sierra de Santo Domingo range at elevations of 2690 and $3900 \mathrm{~m}$ a.s.1. These are the northernmost stations of $A$. wilsonii.

Penetration of austral-derived cool-adapted bryophytes into the equatorial mountains is not a rare biogeographical pattern, yet it has not gained too much attention in descriptive studies and no summary has hitherto been given. A number of moss species extend into the tropics along the transamerican track, which is the most continuous and efficient transtropical route, and has served for the northward migration of Gondwanan species. Beside Acroschisma wilsonii, the most typical representatives of this group are Bryum clavatum (Schimp.) Müll.Hal. and B. campylothecium Taylor (Ochi, 1980), Bucklandiella didyma (Mont.) Bedn.-Ochyra \& Ochyra (Bednarek-Ochyra et al., 1999), Chrysoblastella chilensis (Mont.) Reimers (Blockeel et al., 2002), Dicranella campylophylla (Taylor) A.Jaeger (Ochyra \& Newton, 1985 as D. cardotii (R.Br.bis) Dixon), D. hookeri (Müll.Hal.) Cardot (Blockeel et al., 2007; Ochyra et al., 2013; Ochyra \& Bednarek-Ochyra, 2014), Hymenoloma antarcticum (Müll.Hal.) Ochyra (Ochyra \& Bednarek-Ochyra, 2015a), Lepyrodon tomentosus (Hook.) Mitt. (Allen, 1999), Notoligotrichum trichodon (Hook. \& Wilson) G.L.Sm. (Smith, 1971; Ellis et al., 2012b), Plagiothecium orthocarpum Mitt. (Ochyra et al., 2002, 2008a), Schistidium andinum (Mitt.) Ochyra and $S$. praemorsum (Müll.Hal.) Herzog (Ochyra et al., 2008a, 2008b).

2. Bartramia pomiformis Hedw.

Contributor: H. Bednarek-Ochyra

Ethiopia: (1) Bale Mountains, above Goba, $3450-3500 \mathrm{~m}$ a.s.1., $6^{\circ} 54^{\prime} \mathrm{N}, 39^{\circ} 56^{\prime} \mathrm{E}$; upper montane Philippia-Hagenia forest on $35-40^{\circ}$ steep rocky upper slope with relatively little human disturbance; epiphytic moss, also on smaller branches; 4 March 1990, leg. S. \& G. Miehe 3295 (KRAM); (2) same locality, $3500 \mathrm{~m}$ a.s.1., ericaceous belt, Philippia Klotzsch woodlands and thickets merging with upper montane Philippia-Hagenia forest, Philippia keniensis S.Moore scrub forest on $25^{\circ} \mathrm{E}$ to SSEfacing slopes of deep valley; grazed, minor associate of ground moss community; 2 March 1990, leg. S. \& G. Miehe 3128 (KRAM).
Bartramia pomiformis is a boreal-montane species having a continuous circumpolar range in the northern hemisphere and its global geographical distribution was reviewed and mapped by Ochyra et al. (1992). The species was reported from some bipolar stations in southern South America (Greene, 1986), New Zealand (Beckett, 1896) and Australia (Streimann \& Curnow, 1989), but these records proved to be erroneous and were based upon misdeterminations of the herbarium specimens, which actually belonged to B. robusta Hook.f. \& Wilson (Dixon, 1926; Fransén, 2004) and B. halleriana Hedw. (Matteri, 1984, 1985). Nevertheless, this species does occur outside the Holarctic and was once collected in the Bale Mountains, Ethiopia (Miehe \& Miehe, 1994a; O'Shea, 2006). Two specimens have been recorded, one of which is in fine fruiting condition, and because no data of these collections have been provided in the earlier literature, the relevant details of the voucher specimens are cited herein. The species seems to be rare, occurring in woodlands and scrubs in the ericaceous belt dominated by Philippia keniensis and Erica trimera (Engl.) Beentje at an elevation of 3450-3500 $\mathrm{m}$ a.s.1. This community is characterised by a relatively high humidity resulting in the development of a rich bryophyte vegetation (Miehe \& Miehe, 1993, 1994a, 1994b), which yielded a number of new moss records for Ethiopia (e.g. Blockeel et al., 2004; Ellis et al., 2016a). Some species recorded by the Miehes in the Bale Mountains proved to be of great phytogeographical importance. Apart from B. pomiformis, three other species have been newly recorded in Africa, including Plagiomnium undulatum (Hedw.) T.J.Kop. (Koponen, 1993), Entodon concinnus (De Not.) Paris (Ochyra \& Bednarek-Ochyra, 2000) and Plagiothecium lucidum (Hook.f. \& Wilson) Paris (Ochyra et al., 2000). The two former species are interesting examples of the deep penetration of northernderived species into the tropics, and the latter represents penetration of southern-derived species into the tropics (Bednarek-Ochyra \& Plášek, 2017).

3. Brachythecium subpilosum (Hook.f. \& Wilson) A.Jaeger

Contributors: M. Bačkor, M. S. Sabovljević and M. Goga

Antarctica, James Ross Island: rocky wet ground; $63^{\circ} 47.2670^{\prime} \mathrm{S}, 57^{\circ} 47.7330^{\prime} \mathrm{W}, 11$ February 2017, leg. M. Bačkor s.n., det. M. S. Sabovljević and M. Goga (BEOU; Košice University bryophyte collections).

The bryophyte flora of Antarctica is rather poorly known. However, climatic changes and the disappearance of permanent ice increases the interest in new records in the region (Ochyra et al., 2008b).

During a few months research on lichens on James Ross Island, Antarctica, M. Bačkor made a small collection of bryophytes. Among the species identified in 
this collection was Brachythecium subpilosum. This is an amphiatlantic temperate moss, common in Magellanean region of Western Patagonia reaching north to Valdivia ( $c a 0^{\circ} \mathrm{S}$ ) (Ochyra et al., 2008b), Tierra del Fuego and the Falkland Islands. It is also reported from the subantarctic islands of South Georgia, Kerguelen, Tristan de Cunha islets and Gough Island (Ochyra et al., 2008b). In the Antarctic it has been collected twice, on the Davis Coast (west side of Antarctic Peninsula) over 100 years ago (Ochyra et al., 2008b) and recently on Livingston Island (South Shetland Islands) (Lara \& Pertierra in Ellis et al., 2012a). This present report constitutes a new record for the bryophyte flora of James Ross Island. The collection was sterile, as were the specimens from the Davis Coast and Livingston Island, but the species frequently fruits on South Georgia and Tierra del Fuego.

4. Bucklandiella curiosissima (Bedn.-Ochyra \& Ochyra) Bedn.-Ochyra \& Ochyra

Contributor: H. Bednarek-Ochyra

New Zealand, North Island: Manawatu-Manganui Region, Ruahine Range, Ruahine Forest Park, Wharite Peak, ca $10 \mathrm{~km} \mathrm{~N}$ of Woodville on Whariti Road, $40^{\circ} 15.3^{\prime} \mathrm{S}, 175^{\circ} 51.5^{\prime} \mathrm{E}, 900 \mathrm{~m}$ a.s.l., MZMS 260 T2 3531018 , on grassy verge at side of road through scrub of Olearia colensoi Hook.f., Pseudowintera colorata (Raoul) Dandy, Griselinia lucida G.Forst., Fuchsia excorticata (Forst. \& Forst.f.) L.f., amongst Campylopus clavatus (R.Br.) Wilson and grasses, 10 December 2005, leg. Patrick J. Brownsey s.n. (WELT M37344 as Racomitrium pruinosum (Wilson) Müll.Hal.).

Bucklandiella curiosissima is a New Zealand endemic species which was described as new to science (Bednarek-Ochyra \& Ochyra, 1996). Although it is a very large and handsome moss with a unique overall appearance, a few old collections of this species have been mistaken for Racomitrium pruinosum or $R$. lanuginosum (Hedw.) Brid. and stored in herbaria under these names. For a long time this species has been known only from Canterbury, Otago and Nelson regions in the South Island (Bednarek-Ochyra \& Ochyra, 1996; Fife, 2000; Ellis et al., 2014b). During revisionary studies of the herbarium collections of the broadly conceived genus Racomitrium Brid. for a monograph of the subfamily Racomitrioideae in New Zealand, two specimens of $B$. curiosissima were detected from the Wellington region in the North Island (Ellis et al., 2015). Herein, the next collection of this species was discovered in the Ruahine Range in the ManawatuManganui region in the central part of the North Island and this is the northernmost locality for B. curiosissima.

Bucklandiella Roiv. is the largest segregate of the traditionally understood genus Racomitrium (Sawicki et al., 2015) and it was taxonomically very underworked, as almost all species of this genus described from the southern hemisphere were lumped with the broadly conceived $R$. crispulum (Hook.f. \& Wilson) Wilson (Clifford, 1955; Bednarek-Ochyra, 2015a). However, detailed taxonomic studies on this complex resulted in the discovery of several new species (Fife, 1984; Bednarek-Ochyra \& Ochyra, 1996, 2010, 2011; Bednarek-Ochyra et al., 2014), the reinstatement of some species from obsolescence (Ellis et al., 2011; Bednarek-Ochyra, 2014) and the discovery of some species described from elsewhere (Blockeel et al., 2008; Ellis et al., 2014a). Accordingly, the genus Bucklandiella is represented in New Zealand by 12 species.

5. Buxbaumia viridis (DC.) Moug. \& Nestl.

Contributors: K. Torzewski and A. Kazienko

Poland: Sudetes, Karkonosze Mountains, Biały Potok Valley on the eastern slope of Mt Turek, $50^{\circ} 45^{\prime} 44^{\prime \prime} \mathrm{N}, 15^{\circ} 43^{\prime} 17^{\prime \prime} \mathrm{E}, 920$ m. a.s.1, 10 October 2016, leg. K. Torzewski \& A. Kazienko s.n. (WRSL).

Buxbaumia viridis is broadly but sparsely distributed, and rarely encountered in Poland and Europe (Soldan, 1992). Therefore, it was included in the Red Data Book of European Bryophytes (Schumacker \& Martiny, 1995) as Endangered (category V), in the list of species in Annex I of the Bern Convention (1979) and in Annex II to Habitats Directive 92/43/ EEC (1992). Since 2001, B. viridis has been protected by law in Poland (Regulation of 2014). Historically the species was common in the Sudetes, but now only two locations are known in the western mountain range (Smoczyk \& Wierzcholska, 2008; Cykowska \& Vončina, 2011). Buxbaumia viridis was recorded in the Czech part of the Karkonosze Mountains (Horáková, 2011), but never in the Polish part (Fudali \& Wojtuń, 2013). The new stand of B. viridis was found in the Karkonosze National Park in Biały Potok Valley on the eastern slope of Mt Turek. The new site was located in a 50-year-old spruce forest, resembling the association Calamagrostio villosaePiceetum. There was only one sporophyte on an $0.8 \mathrm{~m} \mathrm{log}$ of Picea abies (L.) H.Karst. Co-occurring species: Cephalozia bicuspidata (L.) Dumort., Dicranum scoparium Hedw., Herzogiella seligeri (Brid.) Z.Iwats. and Lophocolea heterophylla (Schrad.) Dumort.

6. Cephaloziella elachista (J.B.Jack ex Gottsche \& Rabenh.) Schiffn.

\section{Contributor: F. Prosser}

Italy: northern province of Trento, Rendena Valley, about $1 \mathrm{~km} \mathrm{SW}$ of Madonna di Campiglio, in the bog named Palù Marc (Natura 2000 area IT3120070), 9730/4 (Central European Mapping Scheme); $46^{\circ} 12^{\prime} 50.2^{\prime \prime} \mathrm{N}, 10^{\circ} 48^{\prime} 43.9^{\prime \prime} \mathrm{E}, 1695 \mathrm{~m}$ a.s.1., growing in association with Sphagnum subnitens Russow \& 
Warnst., 31 August 2017, leg. F. Prosser \& G. Tomasi s.n., det. F. Prosser, confirm. M. Aleffi (01080 Prosser priv. herb.).

Cephaloziella elachista is a boreal atlantic species growing mainly in Sphagnum L. bogs (Nebel \& Philippi, 2005). It is easily recognised by its small, distant leaves that are deeply divided into two acute lobes, and most of which carry an obvious tooth close to their base. Due to its small size, the species is easily overlooked. The present record was found during botanical surveys to monitor Natura 2000 areas. The plot where $C$. elachista occurred was rich in Sphagnum subnitens. In the same plot uncommon vascular plants were present, such as Carex pauciflora Lightf., Drosera anglica Huds., Scheuchzeria palustris L. and Vaccinium microcarpum (Turcz. ex Rupr.) Schmalh. Aleffi (2005; see also Aleffi et al., 2008), after a review of literature and herbarium data, excluded C. elachista from Italy. In particular, he considered as uncertain two records by Gerdol (1993) from two Sphagnum bogs in the southern Carnian Alps, as voucher specimens were lacking. The confirmation of $C$. elachista in Italy is not surprising. Although rare and threatened, it is reported in neighbouring countries such as Austria and Switzerland (Hodgetts, 2015). Although further findings in Sphagnum bogs in the Italian Alps are to be expected, the species is surely rare in Italy because its potential habitat is scarce.

7. Codriophorus mollis (Cardot) Bedn.-Ochyra \& Ochyra

Contributor: H. Bednarek-Ochyra

Colombia: Departamento del Putumayo, Municipio de Colón, Reserva Natural La Rejoya, Orillas río Negro, $2700 \mathrm{~m}$ a.s.1., $1^{\circ} 17^{\prime} \mathrm{N}, 76^{\circ} 53^{\prime} \mathrm{W}$, moss on rocks in river, growing as a small admixture in patches of Bucklandiella subsecunda (Harv.) Bedn.Ochyra \& Ochyra and very scarce B. lamprocarpa (Müll.Hal.) Bedn.-Ochyra \& Ochyra, 10 November 1996, leg. B. R. Ramírez P. 10.254A (MO, duplicate from Herbario Universidad de Nariño, PSO).

Codriophorus mollis is a distinct species. It differs from its close relative, C. acicularis (Hedw.) Bedn.Ochyra \& Ochyra, by a set of morphological and anatomical traits, including its soft texture and the often unbranched, thread-like appearance of its plants. The leaves also possess a slender costa, which is commonly spurred and forked at the apex, and reaches half to three quarters of the way up the leaf (BednarekOchyra, 2006). It is a hydrophyte growing attached to periodically flooded stones and boulders in rivers, stream beds and watercourses, as well as on wet cliffs, seeping outcrops and wet rock ledges. Although ecologically it can be classified as rheophytic, C. mollis does not exhibit any adaptations to habitats with swiftly flowing water, which has a destructive impact on plants. The leaves have an entirely unistratose lamina with a fairly narrow and not markedly strong costa. Although such features are not unique among rheophytic mosses (Ochyra, 1986, 1987; Touw \& Ochyra, 1987; Shevock et al., 2006, 2011), they do contrast with many species growing in similar habitats that possess typical rheophytic adaptations.

Codriophorus mollis is a typical Beringian, circumnorth Pacific moss species, which is frequent in north-western North America. It ranges from Washington to south-eastern Alaska, and through the Aleutian arc reaches the Far East of Asia, where it extends from Kamchatka to northern Honshu in Japan. Additionally, this is the only species of the genus that penetrates deeply into the tropics. Hitherto, it was recorded at an altimontane elevation of $4100 \mathrm{~m}$ a.s.l. in the páramo of the Sierra Nevada del Cocuy Chita within the Cordillera Oriental of the northern Andes in the Province of Boyacá in Colombia. Herein, the species is recorded from Departamento del Putumayo, bordering Ecuador and Peru in the south-west of Colombia. It was found at a relatively low elevation of $2700 \mathrm{~m}$ a.s.1. in the Colombian Massif in the Amazonian Region. The collection was found on rocks in a river, growing as a small admixture in patches of Bucklandiella subsecunda, which occasionally occurs in such habitats, and some plants of B. lamprocarpa, which is an Afro-American cool-adapted rheophyte, occurring in the Subantarctic (Bednarek-Ochyra \& Ochyra, 1998), South Africa (Bednarek-Ochyra \& Ochyra, 2012a; Ochyra \& van Rooy, 2013) and southern South America (Bednarek-Ochyra \& Ochyra, 1994, 2012b; Bednarek-Ochyra et al., 1996), extending to the central and northern Andes (Bednarek-Ochyra, 2015b) and East Africa (Ochyra et al., 1988). Thus, the equatorial mountains in Colombia are a meeting point of southern cooladapted moss species with the northern-derived Laurasian moss species that occur on remote stations in the tropics. The northern Andes are a well documented outpost for many northern bryophytes in the Neotropics (Menzel, 1986; Gradstein \& Ván̆a, 1987; Ochyra \& Bednarek-Ochyra, 2002).

8. Crossidium squamiferum (Viv.) Jur.

Contributors: J. Nagy and P. Erzberger

Hungary: Pest County, Börzsöny Mountains (8279.2, Central European Mapping Scheme), southwest of the settlement Nagymaros, on exposed andesitic rocks partially covered by a thin layer of loess, at the hill Szürke-hegy, $c a 160 \mathrm{~m}$ a.s.l., $47^{\circ} 46^{\prime} 12.8^{\prime \prime} \mathrm{N}$, $18^{\circ} 56^{\prime} 15.9^{\prime \prime} \mathrm{E}, 19$ May 2017, leg. József Nagy \& Peter Erzberger (B-Erzberger 23160, dupl. BP, herb. J. Nagy, herb. Cs. Németh), det. P. Erzberger, conf. B. Papp. 
Bryophytes associated with the collection include Didymodon acutus (Brid.) K.Saito, Encalypta vulgaris Hedw., Microbryum curvicollum (Hedw.) R.H.Zander, Pseudocrossidium hornschuchianum (Schultz) R.H.Zander, Pterygoneurum subsessile (Brid.) Jur., Syntrichia calcicola J.J.Amann (det. P. Erzberger, conf. M. T. Gallego), S. caninervis Mitt. var. gypsophila (J.J.Amann ex G.Roth) Ochyra, Grimmia laevigata (Brid.) Brid., G. orbicularis Wilson, G. ovalis (Hedw.) Lindb., G. plagiopodia Hedw., G. pulvinata (Hedw.) Sm., Pleurochaete squarrosa (Brid.) Lindb., Weissia longifolia Mitt., Campyliadelphus chrysophyllus (Brid.) R.S.Chopra, Phascum cuspidatum Hedw. var. piliferum (Hedw.) Hook. \& Taylor, Schistidium brunnescens Limpr. and Tortella fasciculata (Culm.) Culm. Some of the bryophyte taxa growing in the vicinity of $C$. squamiferum were collected during subsequent visits with B. Papp, Cs. Németh and A. Mártonffy on 17 and 21 June 2017.

Our plants of Crossidium squamiferum were in fine fruiting condition, with a twisted peristome, corresponding to the typical variety (straight peristome in var. pottioideum (De Not.) Mönk.). Of the seven species of the genus occurring in Europe (Hill et al., 2006), two were already known to occur in Hungary (Papp et al., 2010): C. crassinervium (De Not.) Jur. and $C$. laxefilamentosum W.Frey \& Kürschner. From these, $C$. squamiferum differs by its conspicuously hyaline, broad, flat to incurved upper leaf margins, consisting of very incrassate cells with small lumina. The photosynthetic filaments on the ventral surface of the costa have papillose end cells (smooth in C. laxefilamentosum) and are also strongly thick-walled.

The site of this newly discovered member of the Hungarian bryoflora is at the southern limit of the Börzsöny Mountains, facing the valley of the Danube. The vegetation and flora indicate a submediterranean climate, with extensive stands of Quercus pubescens Willd. and the occurrence of locally rare vascular plant species. The site is a very steep slope of volcanic bedrock (andesite), very difficult to access and fully exposed, with the cover of loess partially removed by erosion, but also loess is at times washed onto the slope from deposits above with loess steppe and woody vegetation. This explains the remarkable mixture of acidophytic and basiphytic bryophytes found. The population of $C$. squamiferum covers an area of $c a 0.5$ ha, the number of its cushions, several of them palm-sized, was estimated to amount to at least 1000 .

It is difficult to decide whether this is a relatively new arrival to the country or whether the species has been growing here for decades without being noted. Although $C$. squamiferum is a very distinctive plant easily recognised in the field when viewed with a hand lens, at a superficial glance from some distance a cushion of $C$. squamiferum might be passed over as some other hoary moss, e.g. a species of Grimmia. There is no mention of the locality 'Szürke-hegy' in Vajda's account of the bryophytes of the Börzsöny Mountains (Vajda, 1966), nor is there any evidence in Boros's field diaries (Boros, 1915-1971) that the site had been visited by the most outstanding Hungarian bryologists of the $20^{\text {th }}$ century. These facts together with the extensive size of the population of $C$. squamiferum suggest that the species became established a rather long time ago.

Among the countries surrounding Hungary, $C$. squamiferum occurs in Austria (red-listed 3, corresponding to $\mathrm{EN}=$ Endangered), Slovenia $(\mathrm{DD}=$ Data Deficient), Croatia, Serbia, and Romania (EN) (Hodgetts, 2015). The most northerly occurrences of C. squamiferum in Europe are in England, where it has also been discovered only recently (Bosanquet, 2014), Germany (Meinunger \& Schröder, 2007) and the Czech Republic (Kučera et al., 2012). Outside Europe, Macaronesia, North Africa, eastern, central and south-western Asia, North America, and New Zealand constitute the range of this submediterranean species (Zander, 1993; Ahrens, 2000).

\section{Ephemerum cohaerens (Hedw.) Hampe}

Contributor: V. Hugonnot

France: Landes, Saint-Cricq-du-Gave, $10 \mathrm{~m}$ a.s.1., $01^{\circ} 00^{\prime} 38^{\prime \prime} \mathrm{W}, 43^{\circ} 32^{\prime} 12^{\prime \prime} \mathrm{N}, 18$ November 2017, leg. V. Hugonnot s.n. (Private herb. of author); HauteGaronne, Portet-sur-Garonne, Réserve naturelle de la confluence Garonne-Ariège, $140 \mathrm{~m}$ a.s.l., $01^{\circ} 24^{\prime} 37.39^{\prime \prime} \mathrm{E}, 43^{\circ} 31^{\prime} 4.21^{\prime \prime} \mathrm{N}$, October 2011, leg. M. Wright s.n., (comm. J. Celle); Alpes-de-HauteProvence, Moustiers-Sainte-Marie, Lac de SainteCroix, $480 \mathrm{~m}$ a.s.1., $06^{\circ} 13^{\prime} 11^{\prime \prime} \mathrm{E}, 43^{\circ} 48^{\prime} 46^{\prime \prime} \mathrm{N}, 7$ November 2017, leg. V. Hugonnot s.n. (Private herb. of author).

Ephemerum cohaerens is a 'European Temperate' moss, scattered through Europe, eastern Asia and eastern North America. The three localities reported here are in south-eastern and south-western France, where the species had not been previously recorded. This means that E. cohaerens is undoubteldy more widespread than the few French records would suggest.

The habitats of these collections consisted of periodically inundated muddy soil in open vegetation of vascular plants. Remarkably, associated bryophytes were the same at all three sites: Physcomitrella patens (Hedw.) Bruch \& Schimp., Bryum klingraeffii Schimp., Dicranella staphylina H.Whitehouse and Riccia cavernosa Hoffm. emend. Raddi. All sites are artificial reservoirs and two of them are gravel excavations fed with aquifers. For unknown reasons, the populations of the species seemed to be extremely patchy at one site in spite of the homogeneous and mostly very open belts 
of vegetation. The observations were made during the same period (mid November), but the sporophytes in the Alpes-de-Haute-Provence locality were only beginning to differentiate, whereas those in Landes were fully ripe. This probably reflected the time ellapsing since exposure of the substrate that allowed the ephemerals to grow. The gametophyte, including protonemata and leaves, was sufficiently distinctive to be identified without difficulty. The protonemata had distinctive fastigiated branches, and the leaves had a characteristically erect, sub-sheathing, abruptly shouldered, broadly oblong base, some leaves possessed a squarroserecurved, linear apex.

10. Fissidens curvatus Hornsch.

Contributors: S. Poponessi, M. Aleffi, R. Venanzoni and D. Gigante

Italy: Umbria Region, (1) Province of Terni, 'Parco Fluviale del Nera' Regional Park, Marmore Waterfall, 'Petrifying springs with tufa formation (Cratoneurion)', $42^{\circ} 33.212^{\prime} \mathrm{N}, 12^{\circ} 42.802^{\prime} \mathrm{E}$, ca $307 \mathrm{~m}$ a.s.1., in a rock slit (on a thin soil layer), 23 March 2016, leg. and det. S. Poponessi s.n. (PERU). (2) Province of Perugia, Boschi di Ferretto-Bagnolo. This is a Special Area of Conservation (SAC IT5210020), $43^{\circ} 9.578^{\prime} \mathrm{N}, 1^{\circ} 59.466^{\prime} \mathrm{E}, \quad$ ca $275 \mathrm{~m}$ a.s.1., on clayey soil at the edge of a temporary pond, 05 May 2016, leg. and det. S. Poponessi (PERU).

These investigations focused on a system of Mediterranean temporary ponds categorised as a priority habitat under the EU Directive 92/43/EEC and listed in Annex I with the code 3170* 'Mediterranean temporary ponds.' The research was carried out during a study of the bryophyte component started in 2015 (Ellis et al., 2015, 2016b; Poponessi et al., 2016; Ellis et al., 2017a).

The locality for the first collection, from 'Parco Fluviale del Nera', is in a Special Area of Conservation (SAC IT5220017) and a Special Protection Area (SAC IT5220025) of the Natura 2000 EU-wide network due to the presence of the EU Directive 92/43/EEC Annex I priority Habitat $7220^{*}$ 'Petrifying springs with tufa formation (Cratoneurion)' (Biondi et al., 2012).

This is the first record of Fissidens curvatus for two areas in the Umbria region. The ecological features and substrate at the two sites were very different, but the humidity of the environment was similar during the period of observation. According to Dierßen (2001), this species is subneutrophytic and mesohygrophytic, which agrees with the climatic features of the localities in which our specimens were discovered. We confirm, as already noticed for the British sites, that the habitat of this species cannot be described unequivocally, because it was reported both on clay soils in open spaces and on rock (Lockhart et al., 2012).
The present discovery of $F$. curvatus is an interesting addition to the moss flora of Italy (Aleffi et al., 2008). Recent records include only Sardinia (Frahm et al., 2008), while older records included Calabria (Giacomini, 1938) Tuscany (Levier, 1905) and Sardinia (Venturi, 1883), showing a preminently Thyrrhenian distribution for this species in Italy.

Indeed, this taxon has been assigned to the Mediterranean-Atlantic geographical element (Smith, 2004). According to Hodgetts (2015), it is considered as DD (Data Deficient) for Italy, Hungary and Montenegro, DD* (Data Deficient but recently recorded) for Albania and Bulgaria, CR (Critically Endangered) for Slovakia, RE (Regionally Extinct) for Ireland and EN (Endangered) for Great Britain. Its range includes south-western and Mediterranean regions in Europe, occurring from Macaronesia and the Iberian Peninsula, northwards to Great Britain, eastwards to Croatia, Montenegro, Hungary, Bulgaria and Greece (Lockhart et al., 2012; Ros et al., 2013). The worldwide distribution includes Iran, Turkey, China, India, Japan, North Africa, sub-Saharan Africa and Central and South America (Lockhart et al., 2012).

Fissidens curvatus can be distinguished from other small terricolous Fissidens species with bordered leaves by its tapering leaves with elongate, papillose cells, but it has possibly been overlooked owing to its small size, sporadic occurrence and typically small amounts (Lockhart et al., 2012).

11. Fossombronia foveolata Lindb.

Contributors: S. Ştefănuţ and G. M. Maria

Romania: Sibiu County: 'La Mlacă', near Arpaşu de Sus, $45^{\circ} 42^{\prime} 49^{\prime \prime} \mathrm{N}, 24^{\circ} 38^{\prime} 18^{\prime \prime} \mathrm{E}, 555 \mathrm{~m}$ a.s.1., on mud, 28 September 2017, leg. S. Ştefănuţ \& G. M. Maria, s.n., det. S. Ştefănuţ (BUCA B4840-B4842).

Fossombronia foveolata was collected from the vicinity of a slow-flowing stream. The plants grew along with other bryophytes including Fossombronia wondraczekii (Corda) Dumort. ex Lindb., Solenostoma gracillimum (Sm.) R.M.Schust. and Ephemerum serratum (Schreb. ex Hedw.) Hampe.

This is the first report of Fossombronia foveolata for Romania (Ştefănuţ, 2008; Ştefănuţ \& Goia, 2012). The nearest locality for this species is in Hungary (Hodgetts, 2015). The conservation status of $F$. foveolata in Romania is Critically Endangered -CR B1ab(ii,iii)+2ab(ii,iii).

Note, Fossombronia spore samples were examined and photographed under a JEOL JSM-6610LV microscope.

12. Hygrohypnum styriacum (Limpr.) Broth.

Contributor: T. Kiebacher

Italy: Trentino-Alto Adige, South Tyrol, Pfitsch, on the path between Gliederscharte and Wiener Neustatt, $46^{\circ} 57^{\prime} 20.1^{\prime \prime} \mathrm{N}, 11^{\circ} 40^{\prime} 18.6^{\prime \prime} \mathrm{E}$, ca $2400 \mathrm{~m}$ a.s.l., on 
siliceous rocks in a mountain stream, 17 August 2017, leg T. Kiebacher 1589 (priv. herb. T. Kiebacher), conf. N. Schnyder.

Hygrohypnum styriacum is a northern hemisphere, arctic-alpine species (Jamieson, 1976; Rothero, 2006). It is known from North America (Canada, Greenland, United States) and Europe (Jamieson, 1976; Goldberg, 2003). In Europe, the species has been recorded in Austria, France, Great Britain, Iceland, Norway, Poland, Romania, Slovakia, Spain, Sweden and Switzerland (Hodgetts, 2015).

In the Alps $H$. styriacum seems to be rare. It is known from a few sites in Austria and Switzerland (Grims, 1999; Swiss bryophytes, 2017) and is classified as Vulnerable in the Swiss Red List (Schnyder et al., 2004). The type locality of $H$. styriacum is located in the Austrian Alps (Limpricht, 1882) and approximately $120 \mathrm{~km}$ ENE of the locality where the species has now been found in Italy.

Like most species of the genus, H. styriacum is mostly restricted to running waters (Grims, 1999; Jamieson, 2014). The only report of the species from the Sierra Nevada, however, comes from 'shady hollows on boulder-rich ground in alpine glaciers' (Oliván et al., 2007). At the locality presented here, H. styriacum grew submerged on siliceous rocks in a small stream ( $c a 0.5 \mathrm{~m}$ wide). The specimen was collected in passing and only later determined. Hence, information about the size of the population cannot be provided.

13. Hypnum cupressiforme Hedw. var. filiforme Brid.

Contributors: P. Campisi, M. G. Dia and M. L. Marino

Tunisia: Jendouba, $4.5 \mathrm{~km} \mathrm{~S}$ of Aïn Draham, roadside, $680-700 \mathrm{~m}$ a.s.1. $36^{\circ} 44^{\prime} 20^{\prime \prime} \mathrm{N}, 08^{\circ} 40^{\prime} 57^{\prime \prime} \mathrm{E}, 03$ April 2014, in a humid Quercus L. forest, leg. F. M. Raimondo s.n., det. P. Campisi \& M. G. Dia (PAL).

This report concerns a specimen collected during the 12th 'Iter Mediterraneum' planned in Tunisia by OPTIMA, some records of which were published in Campisi et al. (2015) and Ellis et al. (2017b). This is the first discovery of Hypnum cupressiforme var. filiforme in Tunisia.

Hypnum cupressiforme var. filiforme, characterised by slender filiform plants and almost straight leaves, is a Mediterranean-boreal, moderately acidophyticsubneutrophytic, mesophytic, moderately sciophyticconsiderably photophytic species that grows on tree trunks and vertical cliffs (Dierßen, 2001; Ando, 2012). Hypnum cupressiforme var. filiforme is reported in several countries in Europe and the Mediterranean area, while in North Africa, according to reports that date back more than half a century (Ros et al., 2013), it was known only in Morocco. Its discovery in Tunisia extends its known range in North Africa and improves our knowledge of its total distribution.

14. Jungermannia atrovirens Dumort.

Contributors: S. Shirzadian and S. Akhoondi Darzikolaei

Iran: East Azerbaijan province, $20 \mathrm{~km} \mathrm{SW}$ Kalibar, $47^{\circ} 02^{\prime} \mathrm{N}, 38^{\circ} 52^{\prime} \mathrm{E}, 2100 \mathrm{~m}$ a.s.l., on moist soil, 20 July 1971, leg. S. Shirzadian 0558 B (IRAN).

During an investigation of unidentified bryophyte specimens in the IRAN herbarium, an interesting liverwort species was found new for the bryoflora of Iran.

According to the checklist of the Iranian bryoflora (Akhani \& Kürschner, 2004), four species of Jungermannia L. (i.e. J. gracillima Sm., J. hyalina Lyell, J. leiantha Grolle., and J. subulata A.Evans) were known from Iran. Later, a fifth species, Jungermannia caucasica Váňa was reported for Iran by Kürschner \& Frey (2011). Hitherto, Jungermannia atrovirens in south-western Asia was known only from Turkey and Lebanon (Kürschner \& Frey, 2011).

The species is characterised by dioicous, small, yellowish- to dull-green plants (Kürschner \& Frey, 2011); elliptic, cordate or ovate leaves; and a sporophyte with eplicate perianths that gradually taper to an un-beaked mouth. The species usually grows on basic rock along streams, mostly in forest belts at higher montane elevations, usually between 1200 and $2200 \mathrm{~m}$ a.s.1.

15. Microlejeunea strasbergii Bardat \& Ah-Peng

Contributors: T. Pócs, D. A. Callaghan, C. Reeb and R. L. Andriamiarisoa

Madagascar: Manjakatompo-Ankaratra New Protected Area, Vakinankaratra Region, Antananarivo Province, $19^{\circ} 20^{\prime} 31.5^{\prime \prime} \mathrm{S}, 47^{\circ} 17^{\prime} 15.9^{\prime \prime} \mathrm{E}$, $2140 \mathrm{~m}$ a.s.l., corticolous on stems and twigs of Maesa lanceolata Forssk. at edge of native humid forest remnant, associated with Cololejeunea tanzaniae Pócs and Drepanolejeunea pentadactyla (Mont.) Steph, 16 May 2016, leg. D. A. Callaghan, det. T. Pócs (EGR).

A recently described species assumed endemic to Réunion Island (Ah-Peng \& Bardat, 2011), was classified as 'Vulnerable' under the IUCN Red List criteria due to a small and restricted range on the slopes of the Piton des Neiges volcano (1750-2350 m) (Ah-Peng et al., 2015). The new site in Madagascar has been subject to large-scale deforestation and only remnants of the original humid forest survive. The protected area was established in 2013, though cutting of trees within the native forest, presumably for charcoal production, was witnessed in the reserve during the visit. As on Réunion Island (Ah-Peng \& Bardat, 2011), no male shoots were observed. However, perianths were present, providing the first evidence of sexual reproduction. 
16. Neckeropsis cyclophylla (Müll.Hal.) S.Olsson, Enroth \& D.Quandt

Contributors: J. Enroth and J. R. Shevock

U.S.A. Hawai'i: Hawai'i Island, Hawai'i County, North Hilo District. Kolekole stream about 50 yards from Pacific Ocean. Kolekole Beach Park, Highway 19 near milepost 14 between Hakalau and Honomu, $19^{\circ} 53^{\prime} 00^{\prime \prime} \mathrm{N}, 155^{\circ} 7^{\prime} 15^{\prime \prime} \mathrm{W}, 25 \mathrm{ft}$ a.s.l. In shaded zone of stream on volcanic rocks with soil. Hardwood forest dominated by the Moluccan albizia, 29 October 1999, leg. James R. Shevock 18736 (CAS, $\mathrm{H}, \mathrm{PTBG}$ ).

This tropical species of the Neckeraceae was known as Himantocladium cyclophyllum (Müll.Hal.) M.Fleisch., but it was transferred to Neckeropsis Reichardt by Olsson et al. (2010). A more detailed phylogenetic analysis of Neckeropsis and Himantocladium confirmed that it indeed belongs in Neckeropsis s.s. (Olsson et al., 2016). The species has been illustrated (as H. cyclophyllum) e.g. by Enroth (1989) and $\mathrm{Wu}(2011)$.

Neckeropsis cyclophylla has a wide distribution. According to Enroth (1992), it occurs from the Seychelles through India, southern China, throughout the tropical and subtropical SE Asia, and in many island groups in the Pacific, easternmost in the Society Islands. It has not however been reported from Hawai'i before (Staples et al., 2004). The Hawai'ian habitat near sea level is quite typical for the species, as it favours shaded habitats in lowland forests, and grows on trees and rocks.

17. Pohlia andrewsii A.J.Shaw

Contributor: J. Kučera

Czech Republic: North-eastern Bohemia, Krkonoše Mts., Obří důl valley: E slopes of Mt Studniční hora, boulder scree below the 'Čertova zahrádka' ravine, $50^{\circ} 43^{\prime} 37^{\prime \prime} \mathrm{N}, 15^{\circ} 43^{\prime} 28^{\prime \prime} \mathrm{E}, 1010 \mathrm{~m}$ a.s.l., soil bank along a temporary stream in the scree, 6 September 2017, leg. J. Kučera 19804 (CBFS).

Pohlia andrewsii was described relatively recently (Shaw, 1981) from collections originating from a relatively broad distribution in the northern hemisphere (northern North America, Norway including Svalbard, High Tatra Mountains in Slovakia). Subsequently, the moss was reported from numerous European countries with high or northern montane ranges (Austria, Switzerland, Germany, Italy, France, Finland, Russia; Hodgetts, 2015); in Russia, the species is known to extend to the Far East (Ignatov et al., 2006). The new record represents one of its lowest altitudinal occurrences in Central Europe (only in Switzerland, was the species once recorded at $840 \mathrm{~m}$, www.swissbryophytes.ch) but the site has a typically alpine character, located in the avalanche track in scree (mica-schist, gneiss and porphyrite). Ditrichum heteromallum (Hedw.) E.Britton,
Oligotrichum hercynicum (Hedw.) Lam. \& DC., Barbilophozia sudetica (Nees ex Hübener) L.Söderst., DeRoo \& Hedd. and Diplophyllum obtusifolium (Wahlenb.) Dumort. were recorded as immediate accompanying species, and the alpine Grimmia sessitana DeNot. and Weissia wimmeriana (Sendtn.) Bruch \& Schimp. were recorded nearby. The whole site of the ravine is renowned for the rich flora of moderately to strongly basiphilous montane and alpine bryophytes (Kučera et al., 2004).

18. Rhodobryum roseum (Hedw.) Limpr.

Contributors: E. R. F. Souza, A. Silva Pinto, J. B. Silva and S. F. Lopes

Brazil: Fazenda Ipuarana, Lagoa Seca, Paraíba State, $7^{\circ} 9^{\prime} 29^{\prime \prime} \mathrm{S}, 35^{\circ} 52^{\prime} 02^{\prime \prime} \mathrm{W}, 700 \mathrm{~m}$ a.s.l., on litter, 20 September 2017, leg. E. R. F. Souza 1864 (ACAM).

Rhodobryum roseum is recorded from Europe, Japan, China, eastern and southern Africa, Madagascar, Thailand, North America, Central America, and Brazil (Magill, 1987; Smith, 2004; Tropicos, 2017). In Brazil, it is rare and of the three catalogued records, two are for the north-easten region in Atlantic forest, ombrophilous and mixed ombrophilous forests (Peralta, 2015).

We collected the moss at $700 \mathrm{~m}$ a.s.l. in submontane semideciduous forest of As-type climate, according to the Köppen-Geiger classification (Alvares et al., 2014) with an annual mean rainfall of $970 \mathrm{~mm}$, and a dry season from four to five months (Andrade et al., 1999). Leaves with bordered margins, fast leaf reorientation, and strong costal bands of stereids are attributes potentially adaptive to the conditions of dry environments, since they avoid damage by excess luminosity and optimise water conduction (Kürschner, 2004; Crandall-Stotler \& BartholomewBegan, 2007; Vanderpoorten \& Goffinet, 2009).

Taxonomic characteristics that facilitate its identification are the terminal rosette formed by large leaves with a recurved margin up to $2 / 3$ or more from the leaf base and a serrated upper margin. Rhodobryum roseum is a species very similar to $R$. ontariense, although the latter has a broadly acute apex and longer marginal teeth (Iwatsuki \& Koponen, 1972).

19. Rhynchostegiella litorea (De Not.) Limpr.

Contributors: P. Campisi, M. G. Dia and M. L. Marino

Tunisia: $c a 5 \mathrm{~km}$ SW of Bizerta, sandy coast $\mathrm{N}$ of Habib Arifa, $0-5 \mathrm{~m}$ a.s.1. $37^{\circ} 15^{\prime} 16^{\prime \prime} \mathrm{N}, 09^{\circ} 55^{\prime} 20^{\prime \prime} \mathrm{E}$, 31 March 2014, leg. F. M. Raimondo s.n., det. P. Campisi \& M. G. Dia (PAL).

In the course of studying the bryophyte specimens collected during the 12th 'Iter Mediterraneum' organised by OPTIMA (Tunisia, 24 March-4 April 2014), some noteworthy taxa were found. In addition to the results already published (Campisi et al., 2015; Ellis et al., 2017b), the species Rhynchostegiella litorea is 
here recorded for the first time from Tunisia. This small light green-yellowish moss has been frequently treated as a variety of $R$. tenella. At present, it is recognised as a separate species because of some morphological features that differentiate it from the former, such as the papillose seta, the shorter costa, the larger spores and the wider axillary hairs (Guerra et al., 2014). Moreover, in recent years molecular data have supported this separation (Aigoin et al., 2009). Rhynchostegiella litorea is a Mediterraneanoceanic species, growing on rocks, boulders, tree stems and roots; it is a basiphytic, considerably hygrophytic and shade loving, ahemerobous-oligohemerobous moss (Dierßen, 2001).

The species is widely distributed in Europe and in Macaronesia, where it is listed as Near Threatened in Great Britain and in the Canary Islands (Hodgetts, 2015). In northern Africa, it was already known in Algeria, Morocco and, based on old reports (before 1962), in Libya (Ros et al., 1999, 2013). The new report from Tunisia improves our knowledge of the distribution of this species in North Africa.

20. Rhytidiadelphus loreus (Hedw.) Warnst.

Contributors: S. Shirzadian and S. Akhoondi Darzikolaei

Iran: E. Azerbaijan province, $20 \mathrm{~km}$ SW Kalibar, $47^{\circ} 02^{\prime} \mathrm{N}, 38^{\circ} 52^{\prime} \mathrm{E}, 2100 \mathrm{~m}$ a.s.l., on moist soil, 20 July 1971, leg. S. Shirzadian 0559 B (IRAN).

During an investigation of unidentified bryophyte specimens in the IRAN herbarium, this moss was found new for the bryoflora of Iran.

According to Kürschner and Frey (2011), the Hylocomiaceae in Iran included three valid genera, namely, Ctenidium (Schimp.) Mitt., Pleurozium Mitt., and Hylocomiadelphus Ochyra \& Stebel. In both the checklist of Akhani and Kürschner (2004) and the bryophyte flora for south-west Asia (Kürschner \& Frey, 2011), no species of Rhytidiadelphus is reported from Iran. However, Sharifnia et al. (2012) reported $R$. squarrosus (Hedw.) Warnst., which was already known from Turkey, from Guilan province (N. Iran), and Kürschner and Frey (2011) listed another species of the family Hylocomiaceae; Rhytidiadelphus triquetrus (Hedw.) Warnst., as Hylocomiadelphus triquetrus (Hedw.) Ochyra \& Stebel., reporting the latter from both Iran and Turkey.

Rhytidiadelphus loreus reaches to $15 \mathrm{~cm}$ high, has plicate stem leaves and angular cells not much differentiated. These two characters separate it from both $R$. squarrosus and $R$. subpinnatus (Lindb.) T.J.Kop., which have stem leaves without plications and angular cells that form distinct groups (Smith, 2004). Procumbent or stoloniform shoots, arcuate branches, falcato-secund leaves and denticulate margins are the main distinguishing characters of the species.
Rhytidiadelphus loreus is already known from Turkey (Kürschner \& Frey, 2011). It generally occurs on rocks, fallen logs, humus and at the base of trees in woodlands and other humid habitats.

21. Schistidium falcatum (Hook.f. \& Wilson) B.G.Bremer

Contributors: H. Bednarek-Ochyra and

M. Lebouvier

South Indian Ocean, Iles Crozet, Île de la Possession: (1) valley south of station, east of Mont Branca, $180 \mathrm{~m}$ a.s.1., $46^{\circ} 26^{\prime} 49^{\prime \prime} \mathrm{S}, 51^{\circ} 50^{\prime} 06^{\prime \prime} \mathrm{E}$, on rocks at streamside, 29 December 1978, leg. B. G. Bell 1588 \& 1589 (AAS, KRAM); (2) river in valley leading to Crique de la Chaloupe, $25 \mathrm{~m}$ a.s.1., $46^{\circ} 24^{\prime} 40^{\prime \prime} \mathrm{S}, 51^{\circ} 51^{\prime} 29^{\prime \prime} \mathrm{E}$, on rock in stream, 7 January 1979, leg. B. G. Bell 1655 (AAS, KRAM); (3) Malpassée River west of junction with northern tributary, $160 \mathrm{~m}$ a.s.l., $46^{\circ} 27^{\prime} 02^{\prime \prime} \mathrm{S}$, $51^{\circ} 49^{\prime} 31^{\prime \prime} \mathrm{E}$, on rock in river, 27 January 1979, leg. B. G. Bell 2007 (AAS, KRAM); (4) Grande Cascade, $270 \mathrm{~m}$ a.s.1., $46^{\circ} 25^{\prime} 36^{\prime \prime} \mathrm{S}, 51^{\circ} 48^{\prime} 01^{\prime \prime} \mathrm{E}$, on very wet rock surface, 28 January 1979, leg. B. G. Bell 2080 (AAS, KRAM); (5) valley leading to Crique du Sphinx, $0.5 \mathrm{~km}$ from the sea, $60 \mathrm{~m}$ a.s.l., $46^{\circ} 24^{\prime} 56^{\prime \prime} \mathrm{S}, 51^{\circ} 51^{\prime} 42^{\prime \prime} \mathrm{E}$, on rock in stream, 7 February 1979, leg. B. G. Bell 2285 (AAS, KRAM); (6) stream leading to Crique du Sphinx, $0.5 \mathrm{~km}$ from beach, $20 \mathrm{~m}$ a.s.1., $46^{\circ} 24^{\prime} 53^{\prime \prime} \mathrm{S}, 51^{\circ} 51^{\prime} 52^{\prime \prime} \mathrm{E}$, on rock near stream, 9 February 1979, leg. B. G. Bell 2325 \& 2330 (AAS, KRAM); (7) Vallée des Branloires, Moby Dick Rivière, $1 \mathrm{~km}$ east of les Deux Rouquines, $95 \mathrm{~m}$ a.s.1., $46^{\circ} 24^{\prime} 37^{\prime \prime} \mathrm{S}, 51^{\circ} 46^{\prime} 27^{\prime \prime} \mathrm{E}$, on rocks in river, 10 February 1979, leg. B. G. Bell 2336 (AAS, KRAM); (8) north side of Vallée des Branloires, south-east of Mont de l'Alouette, $60 \mathrm{~m}$ a.s.1., $46^{\circ} 23^{\prime} 04^{\prime \prime} \mathrm{S}, 51^{\circ} 44^{\prime} 48^{\prime \prime} \mathrm{E}$, on rocks in stream, 6 March 1979, leg. B. G. Bell 2775 (AAS, KRAM); (9) near river leading to Crique de la Chaloupe where its two main tributaries join, north-east of Le Donjon, $50 \mathrm{~m}$ a.s.1., $46^{\circ} 24^{\prime} 39^{\prime \prime} \mathrm{S}, 51^{\circ} 51^{\prime} 03^{\prime \prime} \mathrm{E}$, on surface of moist rocks at riverside, 13 March 1979, leg. B. G. Bell 2896 (AAS, KRAM); (10) in the valley of the Rivière du Camp, north of the Alfred Faure base, $60 \mathrm{~m}$ a.s.1, $46^{\circ} 25^{\prime} 20^{\prime \prime} \mathrm{S}, 51^{\circ} 50^{\prime} \mathrm{E}$, on stones in swiftly flowing water in the stream, 10 November 2006, leg. R. Ochyra 100/06 \& 106/06 with Marc Lebouvier (KRAM).

The occurrence of Schistidium falcatum on Île de la Possession in the Îles Crozet archipelago in the subantarctic was incidentally mentioned by Ochyra \& Bell (1984), but no specimens or details of this record were cited. The deficiency of the formal background of the record of this species in this area is substantiated herein by the citation of a number of specimens collected on Île de la Possession. As a typical rheophyte, this species appears to be frequent in stream beds and small rivers, growing attached to stones and boulders 
and usually submerged in swiftly flowing water. The vast majority of species of the genus Schistidium Bruch \& Schimp. are xerophytic, growing on dry and exposed rocks, but hydrophytes are also present in this genus and $S$. falcatum is a typical representative of this group. Most of the hydrophytic species of Schistidium are placed in subg. Canalicularia Ochyra, and were reviewed by Ochyra (2003) who included nine species in the group. However, since then additional species have been described, for example, S. frahmianum Ochyra \& Afonina from Chukotka and Alaska (Ochyra \& Afonina, 2010), S. mucronatum H.H.Blom, Shevock, D.G.Long \& Ochyra and $S$. riparium H.H.Blom, Shevock, D.G.Long \& Ochyra from China (Blom et al., 2011), and $S$. deguchianum Ochyra \& Bedn.-Ochyra from Peru (Ochyra \& Bednarek-Ochyra, 2011), so this group presently consists of 15 species (Ochyra \& Bednarek-Ochyra, 2015b).

Schistidium falcatum is an amphiatlantic subantarctic species having the main centre of its distribution on subantarctic islands, including South Georgia (Bell, 1984) in the South Atlantic Ocean and the Prince Edward Islands (Ochyra \& Hertel, 1990), Îles Crozet and Îles Kerguelen from where it was originally described (Hooker \& Wilson, 1844 as Grimmia falcata Hook.f. \& Wilson) in the Kerguelen Biogeographical Province in the South Indian Ocean. It is most probable that $S$. falcatum is a postglacial coloniser on Île de la Possession, which could have reached this island via long distance aerial dispersal after the Last Glacial Maximum, as is the case with the flora of other subantarctic (Van der Putten et al., 2004, 2009, 2010) and periantarctic islands (Birkenmajer et al., 1985). Potential sources for the origin of the subantarctic populations may be the southern South American localities of the species in Tierra del Fuego and Western Patagonia. They are situated about $7250 \mathrm{~km}$ west of Île de la Possession but the prevailing westerly winds are an excellent dispersal vehicle for plants and animals in the southern hemisphere (Muñoz et al., 2004). This distribution pattern is exhibited by some austral cool-adapted species of liverworts (e.g. Blockeel et al., 2009; Váňa et al., 2010, 2014; Ochyra et al., 2014a) and mosses (e.g. Ochyra \& Lewis Smith, 1998; Ochyra \& Singh, 2008; Li et al., 2009; Ochyra, 2010; Bednarek-Ochyra \& Ochyra, 2013; Ochyra \& Bednarek-Ochyra, 2013; Ochyra et al., 2014b, 2015) which are bicentric in distribution in the austral cool-temperate regions. Considering the present record the moss flora of Îles Crozet consists currently of over 70 species.

22. Schistidium pruinosum (Wilson) G.Roth

Contributors: O. M. Afonina and E. A. Ignatova

Russia: Southern Siberia, Republic of Buryatia, Zabaikalsky National Park, Baikal Lake, Svyatoi
Nos Peninsula, near Kurbulik settlement, $53^{\circ} 42^{\prime} 05.2^{\prime \prime} \mathrm{N}, 109^{\circ} 02^{\prime} 06.5^{\prime \prime} \mathrm{E}, 480 \mathrm{~m}$ a.s.l., E-facing cliffs on lake shore, in crevices, 29 July 2014, leg. Yu.S. Mamontov, 421/1 (LE); Southern Siberia, Zabaikalsky Territory, near Nizhniy Tsasuchei settlement, $50^{\circ} 31^{\prime} \mathrm{N}, 115^{\circ} 02^{\prime} \mathrm{E}, 512 \mathrm{~m}$ a.s.l., bank of Onon River, on rocks, 18 July 2006, leg. Afonina, 5306 (LE).

Schistidium pruinosum is a mainly European species. It is distributed from Great Britain and the south of Scandinavia to the south of France and the mountains of Central Europe. In Asia, it is known from the east of Asia Minor and the Caucasus. It is recorded from the Russian Far East (Khabarovsk Territory, Botchinsky State Nature Reserve) (Ignatova et al, 2013) and recently was found in the Urals (Bashkortostan) (Ignatova \& Blom, 2017). The present localities are the first in Siberia.

Schistidium pruinosum differs from other Schistidium species with a papillose lamina in its small $(6-9 \mu \mathrm{m})$ rounded and ovate leaf cells and the irregularly bistratose lamina in the upper half of the leaf (Blom, 1996).

\section{Sematophyllum substrumulosum (Hampe)}

\section{E.Britton}

Contributor: V. Hugonnot

France: Tarn, Arfons, Parc Naturel Régional du Haut-Languedoc, Montagne Noire, forêt domaniale de la Montagne Noire, $750 \mathrm{~m}$ a.s.1., 43.45240; 2.17467, 7 July 2017, leg. V. Hugonnot s.n. (Private herb. of author).

In Montagne Noire, Sematophyllum substrumulosum occurred in a plantation of Pseudotsuga menziesii (Mirb.) Franco, on small pieces of spongy textured wood almost incorporated in the litter. More exceptionnally the plant colonised logs or stumps. It formed small colonies of several $\mathrm{cm}^{2}, 5-10 \mathrm{~m}$ distant from each other, most probably a reflection of the availability of adequate substrate. Patches were generally embedded in overlying pleurocarpous mats, which probably contribute to maintaining conditions of high humidity. This is especially significant since these conifer plantations are dry habitats during summer. Most frequently associated species were Нурnum cupressiforme Hedw. var. cupressiforme and H. jutlandicum Holmen \& Warncke. Campylopus flexuosus (Hedw.) Brid. and C. introflexus (Hedw.) Brid. are not frequently associated with Sematophyllum substrumulosum since they seem to prefer larger woody debris. On soil, $80 \%$ of the surface was colonised by Pseudoscleropodium purum (Hedw.) M.Fleisch., Thuidium tamariscinum (Hedw.) Schimp. and Polytrichastrum formosum (Hedw.) G.L.Sm. The local ecology is comparable to the available data derived from published records (Matcham et al., 2005; De Zuttere \& Wattez, 2008). Given the dull habitat Sematophyllum substrumulosum may colonise, 
it is probably more widespread in France than current records suggest.

In France, to date Sematophyllum substrumulosum has been reported only from a narrow costal stretch of Oceanic and Mediterranean regions (Hugonnot, 2010). In Montagne Noire, it grows $100 \mathrm{~km}$ from the coast in a montane environment. The species is likely expanding its range by taking advantage of abundant sporophyte production and small spores as underlined by Sérgio et al. (2011) and Bosanquet (2013). The record in Montagne Noire does not fit the modelling of Sérgio et al. (2011) which mostly predict an Oceanic invasion by 2050 . Such predictions are based upon robust climatic scenarios and the assumption that a given species does not change its behaviour across time. This is possibly not the case, as a growing number of studies have shown that species are able to evolve rapidly in response to climate change. Droughts or changes in precipitation may be potent selective factors that lead to modifications of ecological dynamics. This is backed-up by the findings of Bosanquet (2013), which demonstrate more rapid changes in the repartition of Sematophyllum substrumulosum than initially predicted. The question needs to be studied in more detail.

\section{Acknowledgements}

This work was supported by the Natural History Museum, London (BM). The contributions by H. Bednarek-Ochyra were financed through the statutory fund of the W. Szafer Institute of Botany of the Polish Academy of Sciences. She also thanks the curators at AAS, B, MO and WELT for arranging the loan of specimens. The field work of M. Lebouvier on Îles Crozet was organised within the programme 136 ECOBIO of the French Polar Institute (IPEV). F. Prosser thanks Michele Aleffi (Camerino) for confirming the identity of Cephaloziella elachista. Vincent Hugonnot thanks Sam Bosanquet for comments on his note. S. Ştefănuţ acknowledges support by project no. RO1567-IBB03/2017 through the Institute of Biology Bucharest of Romanian Academy. The contribution of Roger Andriamiarisoa, Des Callaghan and Catherine Reeb was made under LAbex BCDIV RICCIA, supported by French state funds managed by ANR within the Investissements d'Avenir Program (reference ANR-11-IDEX-0004-02), with fieldwork authorised by The Malagasy General Directorate of Forests and Tananarivo University Department of Plant Biology (79/16/MEEMF/SG/DGF/DAPT/ SCBT.re). The contributions of O. M. Afonina and E. A. Ignatova were supported by RFBR Grant \# 16-04-01156.

Taxonomic Additions and Changes: Nil.

\section{References}

Ah-Peng, C. \& Bardat, J. 2011. Microlejeunea strasbergii sp. nov. (Lejeuneaceae) from Réunion Island (Mascarenes). Bryologist, 114: 668-73.

Ah-Peng, C., Bardat, J., Pocs, T., Söderström, L., Stamenoff, P. \& Strasberg, D. 2012. Red List of liverworts and hornworts for Réunion (Mascarene archipelago). Phytotaxa, 68: 1-23.

Ahrens, M. 2000. Pottiaceae. In: M. Nebel \& G. Philippi, eds. Die Moose Baden-Württembergs. Stuttgart: Ulmer, pp. 230-370.

Aigoin, D.A., Huttunen, S., Ignatov, M.S., Dirkse, G.M. \& Vanderpoorten, A. 2009. Rhynchostegiella (Brachytheciaceae): molecular re-circumscription of a convenient taxonomic repository. Journal of Bryology, 31(4): 213-21.

Akhani, H. \& Kürschner, H. 2004. An annotated and updated checklist of the Iranian bryoflora. Cryptogamie, Bryologie, 25: $315-47$.

Aleffi, M. 2005. New check-list of the Hepaticae and Anthocerotae of Italy. Flora Mediterranea, 15: 485-566.

Aleffi, M., Tacchi, R. \& Cortini Pedrotti, C. 2008. Check-list of the hornworts, liverworts and mosses of Italy. Bocconea, 22: 1-255.

Allen, B. 1999. A revision of the moss genus Lepyrodon (Leucodontales, Lepyrodontaceae). Bryobrothera, 5: 23-48.

Alvares, C.A., Stape, J.L., Sentelhas, P.C., de Moraes, G., Leonardo, J. \& Sparovek, G. 2014. Köppen's climate classification map for Brazil. Meteorologische Zeitschrift, 22: 711-28.

Ando, H. 2012. Australian Mosses Online. 58. Hypnaceae: Hypnum. Available at: http://www.anbg.gov.au/abrs/Mosses_Online/ Hypnaceae_Hypnum.pdf

Andrade, L.A., Reis, M.G., Reis, G.G. 1999. Classificação ecológica do Estado da Paraíba. Interpolação de dados climáticos por aproximação numérica. Revista Árvore, 23: 23-32.

Beckett, T.W.N. 1896. On New Zealand mosses. Transactions of the New Zealand Institute, 29: 441-45.

Bednarek-Ochyra, H. 2006. A taxonomic monograph of the moss genus Codriophorus P. Beauv. (Grimmiaceae). Kraków: W. Szafer Institute of Botany, Polish Academy of Sciences.

Bednarek-Ochyra, H. 2014. Nomenclatural entanglements associated with Racomitrium chlorocarpum (Grimmiaceae). Phytotaxa, 188(3): 153-61.

Bednarek-Ochyra, H. 2015a. Early records of Racomitrium s. lat. (Grimmiaceae, Musci) in the southern hemisphere and the correct author citations for $R$. crispulum and $R$. rupestre. Cryptogamie, Bryologie, 36: 143-54.

Bednarek-Ochyra, H. 2015b. Bucklandiella lamprocarpa (Musci, Grimmiaceae) in central and northern Andes. Cryptogamie, Bryologie, 36(1): 81-90.

Bednarek-Ochyra, H. \& Ochyra, R. 1994. Racomitrium lamprocarpum (Musci, Grimmiaceae) in southern South America. Fragmenta Floristica et Geobotanica, 39(2): 361-7.

Bednarek-Ochyra, H. \& Ochyra, R. 1996. Racomitrium curiosissimum (Musci, Grimmiaceae), an exquisite new species from New Zealand. Fragmenta Floristica et Geobotanica, 41(2): 973-84.

Bednarek-Ochyra, H. \& Ochyra, R. 1998. Racomitrium lamprocarpum (Müll. Hal.) Jaeg. - an addition to the moss flora of Îles Kerguelen and the Subantarctic. Journal of Bryology, 20(2): 525-8

Bednarek-Ochyra, H. \& Ochyra, R. 2010. Bucklandiella allanfifei (Grimmiaceae), a new moss species from New Zealand, with a note on South American B. striatipila. Journal of Bryology, 32(4): $245-55$.

Bednarek-Ochyra, H. \& Ochyra, R. 2011. Bucklandiella angustissima sp. nov. (Grimmiaceae), a new austral amphipacific species with the smallest capsules and the shortest setae in the genus. Cryptogamie, Bryologie, 32(1): 13-27.

Bednarek-Ochyra, H. \& Ochyra, R. 2012a. The taxonomic status of Racomitrium capense (Bryophyta, Grimmiaceae) from South Africa. Cryptogamie, Bryologie, 33(2): 97-106.

Bednarek-Ochyra, H. \& Ochyra, R. 2012b. A consideration of Bucklandiella (Bryophyta, Grimmiaceae) in South America, with a taxonomic re-assessment of Racomitrium looseri. Nova Hedwigia, 95(1-2): 153-63.

Bednarek-Ochyra, H. \& Ochyra, R. 2013. Diversity of Grimmiaceae subfam. Racomitrioideae in sub-Saharan Africa, including an addition of Bucklandiella striatipila to the moss flora of the continent. Cryptogamie, Bryologie, 34(1): 3-12.

Bednarek-Ochyra, H. \& Plášek, V. 2017. Occurrence of Racomitrium pruinosum (Grimmiaceae, Bryophyta) in New Guinea, with a review of Gondwanan mosses in the tropics. Herzogia, 30(2): 412-26. 
Bednarek-Ochyra, H., Matteri, C.M. \& Ochyra, R. 1996. A major range extension of Racomitrium lamprocarpum (Musci, Grimmiaceae) in South America. Fragmenta Floristica et Geobotanica, 41(2): 995-1000.

Bednarek-Ochyra, H., Ochyra, R. \& Buck, W.R. 1999. The genus Racomitrium (Grimmiaceae) in Brazil, with the first report of R. subsecundum in South America. Brittonia, 51(1): 93-105.

Bednarek-Ochyra, H., Ochyra, R., Sawicki, J. \& Szczecińska, M. 2014. Bucklandiella seppeltii, a new species of Grimmiaceae from Australasia and its phylogenetic position based on molecular data. Turkish Journal of Botany, 38(6): 1214-28.

Bell, B.G. 1984. A synoptic flora of South Georgian mosses: Grimmia and Schistidium. British Antarctic Survey Bulletin, 63: 71-109.

Bern Convention. 1979. Convention on the conservation of European wildlife and natural habitats. Bern: 19.09.1979, European Treaty Series, 104.

Biondi, E., Burrascano, S., Casavecchia, S., Copiz, R., Del Vico, E., Galdenzi, D., Gigante, D., Lasen, C., Spampinato, G. Venanzoni, R., Zivkovic, L. \& Blasi, C., 2012. Diagnosis and syntaxonomic interpretation of Annex I Habitats (Dir. 92/ 43/ EEC) in Italy at the alliance level. Plant Sociology, 49(1): $5-37$.

Birkenmajer, K., Ochyra, R., Olsson, I.U. \& Stuchlik, L. 1985. MidHolocene radiocarbon-dated peat at Admiralty Bay, King George Island (South Shetland Islands, West Antarctica). Bulletin of the Polish Academy of Sciences, Earth Sciences, 33 (1-2): 7-13

Blockeel, T.L., Bruggeman-Nannenga, M.A., Brusa, G., Hedenäs, L. Novotný, I., Ochyra, R., Sabovljević, M.S. \& Townsend, C.C. 2002. New national and regional bryophyte records, 6 Journal of Bryology, 24(4): 329-32.

Blockeel, T.L., Bednarek-Ochyra, H., Ochyra, R., BruggemanNannenga, M.A., Gremmen, N.J.M., Hébrard, J.-P., Luís, L., Matcham, H.W., O'Shea, B.J., Séneca, A., Sérgio, C., SimSim, M., Ştefănuț, S. \& Vieira, C. 2004. New national and regional bryophyte records, 10. Journal of Bryology, 26(4): $305-6$

Blockeel, T.L., Bednarek-Ochyra, H., Ochyra, R., Garilleti, R., Glime, J.M., Lara, F., Mazimpaka, V., Rusińska, A. Schaefer-Verwimp, A., Shabbara, H.M., Söderström, L. Stebel, A., Townsend, C.C., Váňa, J., Yayintaş, Ö.T. \& Żarnowiec, J. 2007. New national and regional bryophyte records, 17. Journal of Bryology, 29(4): 277-83.

Blockeel, T.L., Bednarek-Ochyra, H., Ochyra, R., Duckett, J.G., Erzberger, P., Hedenäs, L., Hugonnot, V., Maier, E., Marková, I., Matcham, H.W., Plášek, V., Pócs, T., Seppelt, R.D., Szücs, P., Thouvenot, L. \& van Zanten, B.O. 2008. New national and regional bryophyte records, 18. Journal of Bryology, 30(2): 161-7.

Blockeel, T.L., Bednarek-Ochyra, H., Ochyra, R., Cykowska, B. Esquivel, M.G., Lebouvier, M., Luis, L., Martins, S., Müller, F., Németh, C.S., Papp, B., Plášek, V., Pócs, T., Sabovljević M., Sérgio, C., Sim-Sim, M., Stech, M., Váňa, J. \& Yayintas, Ö.T. 2009. New national and regional bryophyte records, 21 . Journal of Bryology, 31(2): 132-9.

Blom, H.H. 1996. A revision of the Schistidium apocarpum complex in Norway and Sweden. Bryophytorum Bibliotheca, 49: 1-333.

Blom, H.H., Shevock, J.R., Long, D.G. \& Ochyra, R. 2011. Two new rheophytic species of Schistidium from China. Journal of Bryology, 33(3): 179-88.

Boros, A. 1915-1971. Florisztikai jegyzetek. (Field Diaries). Budapest: Hungarian Natural History Museum (manuscript).

Bosanquet, S.D.S. 2013. Sematophyllum substrumulosum: a rapidly changing picture. Field Bryology, 109: 3-5.

Bosanquet, S.D.S. 2014. Crossidium squamiferum var. squamiferum (Viv.) Jur. in Southern England, new to Britain. Journal of Bryology, 36(2): 118-21.

Campisi, P., Dia, M.G., Domina, G. \& Raimondo, F.M. 2015. Bryophytes collected during the 12th "Iter Mediterraneum" (Tunisia, 24 March - 4 April, 2014). First contribution. Bocconea, 27(1): 63-8.

Churchill, S.P., Griffin, D. III. \& Muñoz, J. 2000. A checklist of the mosses of the tropical Andean countries. Ruizia 17: 1-203.

Clifford, H.T. 1955. On the distribution of Rhacomitrium crispulum (H.f. \& W.) H.f. \& W. Bryologist, 58: 330-4.

Crandall-Stotler, B.J. \& Bartholomew-Began, S.E., 2007 Morphology of mosses (Phylum Bryophyta). In: Flora of North America Editorial Committee, eds. Flora of North
America north of Mexico, Vol. 27. Bryophytes: Mosses, Part 1. New York: Oxford University Press, pp. 3-13.

Cykowska, B. \& Vončina, G. 2011. Recent occurrence of moss Buxbaumia viridis (Bryophyta, Buxbaumiaceae) in the Kłodzko region (Central and Eastern Sudetes, SW Poland). Casopis Slezskěho zemskěho muzea, Opava (A), 60: 85-9.

De Zuttere, P. \& Wattez, J.R. 2008. La présence méconnue de Sematophyllum substrumulosum (Hampe) E.Britton dans la région carnacoise (Dépt. du Morbihan; Bretagne méridionale, France). Sa répartition actuelle en Europe. Nowellia Bryologica, 35: 2-13.

Dierßen, K. 2001. Distribution, ecological amplitude and phytosociological characterization of European bryophytes. Bryophytorum Bibliotheca, 56: 1-289.

Dixon, H.N. 1926. Studies in the bryology of New Zealand, with spezial reference to the herbarium of Robert Brown of Christchurch, New Zealand. Part IV. New Zealand Institute Bulletin, 3: 153-238 + pl. ix

Ellis, L.T., Bednarek-Ochyra, H., Ochyra, R., Calvo Aranda, S.M.T., Colotti, M.T., Schiavone, M.M., Dulin, M.V., Erzberger, P., Ezer, T., Kara, R., Gabriel, R., Hedenäs, L., Holyoak, D.T., Odor, P., Papp, B., Sabovljević, M., Seppelt, R.D., Smith, V.R., Sotiaux, A., Szurdoki, E., Vanderpoorten, A., van Rooy, J. \& Żarnowiec, J. 2011. New national and regional bryophyte records, 26. Journal of Bryology, 33(1): 66-73.

Ellis, L.T., Alegro, A., Bansal, P., Nath, V., Cykowska, B., BednarekOchyra, H., Ochyra, R., Dulin, M.V., Erzberger, P., Garcia, C., Sérgio, C., Claro, D., Stow, S., Hedderson, T.A., Hodgetts, N.G., Hugonnot, V., Kučera, J., Lara, F., Pertierra, L., Lebouvier, M., Liepina, L., Mežaka, A., Strazdina, L., Madžule, L., Rēriha, I., Mazooji, A., Natcheva, R., Phephu, N., Philippov, D.A., Plášek, V., Ć́hal, L., Pócs, T., Porley, R.D., Sabovljević, M., Salimpour, F., Behroozmand Motlagh, M., Sharifnia, F., Akhoondi Darzikolaei, S., Schäfer-Verwimp, A., Šegota, V., Shaw, A.J., Sim-Sim, M., Sollman, P., Spitale, D., Hölzer, A., Stebel, A., Váňa, J., van Roov, J. \& Vončina, G. 2012a. New national and regional bryophyte records, 32 . Journal of Bryology, 34(3): 231-46.

Ellis, L.T., Bednarek-Ochyra, H., Ochyra, R., Cykowska, B., Dulin, M.V., Ezer, T., Kara, R., Flores, J.R., Suárez, G.M., Garcia, C., Martins, A., Sérgio, C., Garilleti, R., Kirmaci, M., Agcagil, E., Kurbatova, L.E., Lebouvier, M., Papp, B., Szurdoki, E., Philippov, D.A., Plášek, V., Pócs, T., Sabovljević, M., Sawicki, J., Sim-Sim, M., Szǘcs, P., Bidló, A., Váňa, J., Vigalondo, B., Lara, F., Draper, I., Virchenko, V.M. \& Wolski, G.J. 2012b. New national and regional bryophyte records, 33. Journal of Bryology, 34(4): 281-91.

Ellis, L.T., Bayliss, J., Bruggeman-Nannenga, M.A., Cykowska, B., Ochyra, R., Gremmen, N.J.M., Frahm, J.-P., Hedderson, T.A., Heras, P., Infante, M.V., Hugonnot, V., Mogro, F., Plášek, V., Č́hal, L., Sawicki, J., Schäfer-Verwimp, A., Stebel, A., Stefănut, S., Váňa, J., Yang, J.-D. \& Lin, S.-H. 2014a. New national and regional bryophyte records, 38. Journal of Bryology, 36(1): 61-72.

Ellis, L.T., Aleffi, M., Tacchi, R., Alegro, A., Alonso, M., Asthana, A.K., Sahu, V., Biasuso, A.B., Callaghan, D.A., Ezer, T., Kara, R., Seyli, T., Garilleti, R., Gil-López, M.J., Gwynne-Evans, D., Hedderson, T.A., Kiebacher, T., Larrain, J., Long, D., Lüth, M., Malcolm, B., Mamontov, Y.S., Newsham, K.K., Nobis, M., Nowak, A., Ochyra, R., Pawlikowski, P., Plášek, V., Č́hal, L., Potemkin, A.D., Puche, F., Rios, D., Gallego, M.T., Guerra, J., Sawicki, J., SchäferVerwimp, A., Segarra-Moragues, J.G., Segota, V., Sofronova, E.V., Ştefănuţ, S., Szücs, P., Bidló, A., Papp, B., Szurdoki, E., Tan, B.C., Váňa, J., Vigalondo, B., Draper, I., Lara, F., Yoon, Y.-J., Sun, B.-Y. \& Nishimura, N. 2014b. New national and regional bryophyte records, 41. Journal of Bryology, 36(4): $306-24$.

Ellis, L.T., Aleffi, M., Bakalin, V.A., Bednarek-Ochyra, H., Bergamini, A., Beveridge, P., Choi, S.S., Fedosov, V.E., Gabriel, R., Gallego, M.T., Grdović, S., Gupta, R., Nath, V., Asthana, A.K., Jennings, L., Kürschner, H., Lebouvier, M., Nair, M.C., Manjula, K.M., Rajesh, K.P., Nobis, M., Nowak, A., Park, S.J., Sun, B.-Y., Plášek, V., Cíhal, L., Poponessi, S., Mariotti, M.G., Sabovljević, A., Sabovljević, M.S., Sawicki, J., Schnyder, N., Schumacker, R., Sim-Sim, M., Singh, D.K., Singh, D., Majumdar, S., Singh Deo, S., Ștefănuț, S., Suleiman, M., Seng, C.M., Chua, M.S., Váňa, J., Venanzoni, R., Bricchi, E. \& Wigginton, M.J. 2015. New national and regional bryophyte records, 42. Journal of Bryology, 37(1): 68-85. 
Ellis, L.T., Asthana, A.K., Srivastava, P., Omar, I, Rawat, K.K. Sahu, V., Cano, M.J., Costa, D.P., Dias, E.M., Dias dos Santos, N., Silva, J.B., Fedosov, V.E., Kozhin, M.N., Ignatova, E.A., Germano, S.R., Golovina, E.O., Gremmen, N.J.M, Ion, R., Ştefănuţ, S., von Konrat, M., Jimenez, M.S., Suárez, G.M., Kiebacher, T., Lebouvier, M., Long, D.G., Maity, D., Ochyra, R., Parnikoza, I., Plášek, V., Fialová, L., Skoupá, Z., Poponessi, S., Aleffi, M., Sabovljević, M.S., Sabovljević, A.D. Saha, P., Aziz, M.N., Sawicki, J., Suleiman, M., Sun, B.-Y., Váňa, J., Wójcik, T., Yoon, Y.-J., Żarnowiec, J. \& Larraín, J. 2016a. New national and regional bryophyte records, 46. Journal of Bryology, 38(1): 47-63.

Ellis, L.T., Agcagil, E., Kırmacı, M., Aleffi, M., Bakalin, V.A., Bednarek-Ochyra, H., Cykowska-Marzencka, B., StryjakBogacka, M., Bojaca, G.F.P., Fantacelle, L.B., Araújo, C.A.T., Maciel-Silva, A.S., Bruno Silva, J., Calleja, J.A., Cano, M.J., Castillo Diaz, J., Gabriel, R., Dias dos Santos, N., Enroth, J., Erzberger, P., Garilleti, R., Hájek, M., Hedenäs, L., Heras, P., Infante, M., Kiebacher, T., Koczur, A., Krawczyk, R., Kučera, J., Lebouvier, M., Lüth, M., Mazimpaka, V., Vigalondo, B., Lara, F., Nagy, J., Németh, Cs., Kovács, A. Nobis, M., Wegrzyn, M., Wietrzyk, P., Norhazrina, N., Vanderpoorten, A., Nowak, A., Poponessi, S., Gigante, D. Venanzoni, R., Plášek, V., Rangel Germano, S., SchäferVerwimp, A., Sérgio, C., Claro, D., Garcia, C.A., Shirzadian, S., Akhoondi Darzikolaei, A., Stebel, A., Suleiman, M., Yong, K.-T., Virchenko, V.M., Vončina, G., Yoon, Y.-J., Choi, H.-G. \& Kim, J.H. 2016b. New national and regional bryophyte records, 49. Journal of Bryology, 38(4): 327-47.

Ellis, L.T., Ah-Peng, C., Aleffi, M., Baráth, K., Brugués, M., Ruiz, E., Buck, W.R., Czernyadjeva, I.V., Erzberger, P., Fantecelle, L.B., Peñaloza-Bojacá, G.F., Araújo, C.A.T., Oliveira, B.A., Maciel-Silva, A.S., Gremmen, N.J.M., Guo, S.-L., Hedderson, T.A., February, E., Wilding, N., Hugonnot, V., Kırmacı, M., Kürschner, H., Lebouvier, M., Mesterházy, A., Ochyra, R., Philippe, M., Plášek, V., Skoupá, Z., Poponessi, S., Gigante, D., Venanzoni, R., Rawat, K.K., Sahu, V., Asthana, A.K., Sabovljević, M.S., Sabovljević, A.D., Schäfer-Verwimp, A. \& Wierzcholska, S. 2017a. New national and regional bryophyte records, 50. Journal of Bryology, 39(1): 99-114.

Ellis, L.T., Afonina, O.M., Andriamiarisoa, R.L., Bednarek-Ochyra, H., Cykowska-Marzencka, B., Stryjak-Bogacka, M., Bell, N.E., Boiko, M., Callaghan, D.A., Campisi, P., Dia, M.G., Marino, M.L., Proenzano, F., Eckstein, J., Enroth, J., Erzberger, P., Ezer, T., Gargano, M.L., Ginzburg, E., Górski, P., Gradstein, S.R., Reeb, C., Hannoire, C., Infante, M., Jukonienè, I., Kushnevskaya, E.V., Lebouvier, M., Nagy, J., Opmanis, A., Plášek, V, Skoupá, Z, Sabovljević, M.S., Sabovljević, A.D., Shevock, J.R., Singh, D.K., Majumdar, S., Skudnik, M., Uselienè, A., Venturella, G., Węgrzyn, M., Wietrzyk, P., Yoon, Y.J., Kim, J.H. \& Yücel, E. 2017b. New national and regional bryophyte records, 53. Journal of Bryology, 39(4): 368-87.

Enroth, J. 1989. Bryophyte flora of the Huon Peninsula, Papua New Guinea. XXVII. Neckeraceae (Musci). Acta Botanica Fennica, 137: 41-80

Enroth, J. 1992. Notes on the Neckeraceae (Musci). 13. Taxonomy of the genus Himantocladium. Annales Botanici Fennici, 29 79-88.

Fife, A. 1984. Records of new or otherwise interesting mosses in New Zealand, including a new species of Racomitrium. New Zealand Journal of Botany, 22: 1-6.

Fife, A.J. 2000. A synopsis of the New Zealand species of Schistidium (Grimmiaceae; Musci), with observations on a little known species of Racomitirum. New Zealand Journal of Botany, 38(2): 191-204.

Frahm, J.-P., Lüth, M., Van Melick, H. 2008. Kommentierte Artenliste der Moose von Sardinien. Archive for Bryology, 31: $1-13$.

Fransén, S. 2004. A taxonomic revision of extra-Neotropical Bartramia section Vaginella C.Müll. Lindbergia, 29: 73-107.

Fudali, E. \& Wojtuń, B. 2013. Mchy i Wątrobowce [Mosses and liverworts]. In: R. Knapik \& A. Raj, eds, Przyroda Karkonoskiego Parku Narodowego. Jelenia Góra: Karkonoski Park Narodowy, pp. 199-206. photos 1-16. (In Polish).

Gerdol, R. 1993. The vegetation of wetlands in the southern Carnian Alps (Italy). Gortania, 15: 67-107.

Giacomini, V. 1938. Revisione delle briofite dell'Italia meridionale appartenenti all'erbario A.G. Gasparrini. Parte I: Muschi Atti dell 'Istituto Botanico "Giovanni Briosi”, 10: 305-19.
Goldberg, I. 2003. Mosses of Greenland: list of species in the Herbarium C [accessed 17 October 2017]. Available at: http://www.mobot.org/plantscience/BFNA/ MossesOfGreenland.pdf

Gradstein, S.R. \& Váňa, J. 1987. On the occurrence of Laurasian liverworts in the tropics. Memoirs of the New York Botanical Garden, 45: 388-425

Greene, D.M. 1986. A conspectus of the mosses of Antarctica, South Georgia, the Falkland Islands and southern South America. Cambridge: British Antarctic Survey.

Grims, F. 1999. Die Laubmoose Osterreichs. Catalogus Florae Austriae II. Teil, Bryophyten (Moose), Heft 1, Musci (Laubmoose). Vienna: Österreichische Akademie der Wissenschaften.

Guerra, J., Ríos, D. \& Gallego, M.T. 2014. A revision of the genus Rhynchostegiella (Brachytheciaceae) in the Iberian Peninsula and Balearic Islands. Phytotaxa, 183(3): 193-200.

Habitats directive. 1992. Council Directive 92/43/EEC of 21 May 1992 on the conservation of natural habitats and of wild fauna and flora. Official Journal of the European Union L 206 (amended by Council Directive 97/62/EC of 27 October 1997 adapting to technical and scientific progress Directive 92/43/EEC. Official Journal of the European Union L 305).

Hill, M.O., Bell, N., Bruggeman-Nannenga, M.A., Brugués, M., Cano, M.J., Enroth, J., Flatberg, K.I., Frahm, J.-P., Gallego, M.T., Garilleti, R., Guerra, J., Hedenäs, L., Holyoak, D.T., Hyvönen, J., Ignatov, M.S., Lara, F., Mazimpaka, V., Munoz, J., \& Söderström, L. 2006. An annotated checklist of the mosses of Europe and Macaronesia. Journal of Bryology, 28 (3): 198-267.

Hodgetts, N.G. 2015. Checklist and country status of European bryophytes - towards a new Red List for Europe. Irish Wildlife Manuals, No. 84. National Parks and Wildlife Service, Department of Arts, Heritage and the Gaeltacht, Ireland.

Hooker, J.D. \& Wilson, W. 1844. Musci antarctici; being characters with brief descriptions of the new species of mosses discovered during the voyage of H. M. discovery ships, Erebus and Terror, in the southern circumpolar regions, together with those of Tasmania and New Zealand. London Journal of Botany, 3: 533-56.

Horáková V. 2011. Tajemný šikoušek. Krkonoše a Jizerské hory, 10: 39.

Hugonnot V. 2010. Extension de l'aire de Sematophyllum substrumulosum (Hampe) E.Britton (Sematophyllaceae) au sud-ouest de la France. Le Monde des Plantes, 502: 21-2.

Ignatova, E.A. \& Blom, H.H. 2017. Genus 8. Schistidium. In: M.S Ignatov, ed. Moss Flora of Russia. Vol. 2: Oedipodiales Grimmiales. Moscow: KMK Scientific Press Ltd, pp. 438-551.

Ignatov, M.S., Afonina, O.M., Ignatova, E.A., Abolina A.A., Akatova, T.V., Baisheva, E.Z., Bardunov, L.V., Baryakina, E.A., Belkina, O.A., Bezgodov, A.G., Boychuk, M.A., Cherdantseva, V.Y., Czernyadjeva, I.V., Doroshina, G.Y., Dyachenko, A.P., Fedosov, V.E., Goldberg, I.L., Ivanova, E.I., Jukoniene, I.I., Kannukene, L.I., Kazanovsky, S.G., Kharzinov, Z.Kh., Kurbatova, L.E., Maksimov, A.I., Mamatkulov, U.K., Manakyan, V.A., Maslovsky, O.M., Napreenko, M.G., Otnyukova, T.N., Partyka, L.Y., Pisarenko, O.Yu., Popova, N.N., Rykovsky, G.F., Tubanova, D.Ya., Zheleznova, G.V., Zolotov, V.I. 2006. Check-list of mosses of East Europe and North Asia. Arctoa, 15: 1-130.

Ignatova, E.A., Cherdantseva, V.Ya., Ivanov, O.V., Kostomarova, I.V. \& Ignatov, M.S. 2013. A preliminary list of mosses of the Botchinsky State Nature Reserve (Russian Far East). Arctoa, 22: $207-16$.

Iwatsuki, Z. \& Koponen, T. 1972. On the taxonomy and distribution of Rhodobryum roseum and its related species. Acta Botanica Fennica, 96: 1-22.

Jamieson, D.W. 1976. A monograph of the genus Hygrohypnum Lindb. (Musci). PhD thesis, University of British Columbia

Jamieson, D.W. 2014. Hygrohypnum. In: Flora of North America north of Mexico. Volume 28 Bryophytes: Mosses, Part 2. New York: Oxford University Press, pp. 269-82.

Koponen, T. 1993. Miscellaneous notes on Mniaceae (Bryophyta). XVI. Plagiomnium undulatum (Hedw.) T. Kop. in Ethiopia. Bulletin du Jardin Botanique National de Belgique, 62: 397-402.

Kučera, J., Zmrhalová, M., Buryová, B., Plášek, V. \& Váňa, J. 2004. Bryoflora of the Úpská jáma cirque and adjacent localities of the Eastern Krkonoše Mts. Casopis Slezského Zemského Muzea, Ser. A, 53: 143-73. 
Kučera, J., Váňa, J. \& Hradílek, Z. 2012. Bryophyte flora of the Czech Republic: updated checklist and Red List and a brief analysis. Preslia, 84: 813-50.

Kürschner, H., 2004. Life strategies and adaptations in bryophytes from the near and middle East. Turkish Journal of Botany, 28: 73-84.

Kürschner, H. \& Frey, W. 2011. Liverworts, mosses and hornworts of Southwest Asia. (Marchantiophyta, Bryophyta, Anthocerotophyta). Nova Hedwigia, Beiheft 139: 1-240.

Levier, E. 1905. Appunti di briologia italiana. Terzo elenco (muschi frondosi ed epatiche). Bolletino della Società Botanica Italiana, 6: 206-16

Li, S.-P, Ochyra, R., Wu, P.-C., Seppelt, R.D., Cai, M.-H, Wang, H.Y. \& Li, C.-S. 2009. Drepanocladus longifolius (Amblystegiaceae), an addition to the moss flora of King George Island, South Shetland Islands, with a review of Antarctic benthic mosses. Polar Biology, 32: 1415-25.

Limpricht, K.G. 1882. Neue und kritische Laubmoose. Flora, 65: 201-5.

Lindley, J. 1846. The vegetable kingdom; or, the structure, classification and uses of plants, illustrated upon the natural system. London: Bradbury \& Evans.

Lockhart, N., Hodgetts, N. \& Holyoak, D. 2012. Rare and threatened bryophytes of Ireland. Holywood: National Museums Northern Ireland.

Magill, R.E. 1987. Flora of Southern Africa. Bryophyta, Part 1 Mosses, Fasc. 2 Gigaspermaceae-Bartramiaceae. Pretoria: Botanical Research Institute, pp. 293-443.

Matcham, H.W., Porley, R.D. \& O'Shea, B.J. 2005. Sematophyllum substrumulosum - an overlooked native? Field Bryology, 87: $5-7$.

Matteri, C. 1984. Sinopsis de las especies andino-patagonicas, antarticas y subantarticas de los generos Bartramia, Bartramidula y Conostomum (Bartramiaceae, Musci). Darwiniana, 25: 143-62.

Matteri, C. 1985. Bartramiaceae. In: S.A. Guerrera, I. Gamundi de Amos \& D. Rabinovich de Halperin, eds. Flora criptogámica de Tierra del Fuego. 14(7). Buenos Aires: Consejo Nacional de Investigaciones Científicas y Técnicas de la Republica Argentina, pp. 1-62.

Meinunger, L. \& Schröder, W. 2007. Verbreitungsatlas der Moose Deutschlands. Band 2. Regensburg: Herausgegeben von O. Dürhammer für die Regensburgische Botanische Gesellschaft.

Menzel, M. 1986. Beitrag zur andinen Laubmoosflora von Peru. Willdenowia, 15: 529-55.

Miehe, G. \& Miehe, S. 1993. On the physiognomic and floristic differentiation of Ericaceous vegetation in the Bale Mountains, SE Ethiopia. In: I. Friis, B. Jonsell \& I. Nordal, eds. Mountains botany studies dedicated to Olov Hedberg. Opera Botanica, 121: 85-117.

Miehe, G. \& Miehe, S. 1994a. Ericaceous forest and heathlands in the Bale Mountains of South Ethiopia. Ecology and man's impact. Hamburg: Stiftung Walderhaltung in Africa and Bundesforschungsanstalt für Forst- und Holzwirtschaft.

Miehe, G. \& Miehe, S. 1994b. East African bryophytes, XII. Bryophytes from the Bale Mountains, SE Ethiopia. 1. Phytoecological introduction. In: Ochyra, R., ed. Festschrift com memorating the seventieth birthday of Stanisław Lisowski. Fragmenta Floristica et Geobotanica, 39: 165-219.

Müller, F. 2009. An updated checklist of the mosses of Chile. Archive for Bryology, 58: 1-124.

Muñoz, J., Felicísimo, A.M., Cabezas, F., Burgaz, A.R. \& Martínez, I. 2004. Winds as a long-distance dispersal vehicle in the southern hemisphere. Science, 304: 1144-7.

Nebel, M. \& Philippi, G. 2005. Die Moose Baden-Württembergs. Band 3. Stuttgart: Eugen Ulmer KG.

Ochi, H. 1980. A revision of the Neotropical Bryoideae (Musci) (First part). Journal of the Faculty of Education of the Tottori University, Natural Sciences, 29(2): 49-154.

Ochyra, R. 1986. Touwia laticostata, a remarkable new genus and species of moss from Queensland, Australia. Journal of Bryology, 14(1): 103-8.

Ochyra, R. 1987. A revision of the moss genus Sciaromium (Mitt.) Mitt. I. General remarks and the section Aloma Dusén. Journal of Bryology, 14(3): 453-64.

Ochyra, R. 2003. Schistidium lewis-smithii (Bryopsida, Grimmiaceae) - a new species from the maritime Antarctic, with a note on the Australian S. flexifolium. Nova Hedwigia, 77: $363-72$.

Ochyra, R. 2010. Antipodal mosses: XVI. The first record of the genus Sematophyllum (Sematophyllaceae) in the Subantarctic, with a description of $S$. lebouvieri sp. nov. Cryptogamie, Bryologie, 31(3): 223-32.

Ochyra, R. \& Afonina, O.M. 2010. Schistidium frahmianum (Bryopsida, Grimmiaceae), a new arctic species from Beringia. Tropical Bryology, 31: 139-43.

Ochyra, R. \& Bednarek-Ochyra, H. 2000. Entodon concinnus (De Not.) Paris (Musci) - an addition to the moss flora of tropical Africa. Arctoa, 9: 129-32.

Ochyra, R. \& Bednarek-Ochyra, H. 2002. Pleurozium schreberi (Musci, Hylocomiaceae) recorded for tropical Africa and a review of its world distribution. Cryptogamie, Bryologie, 23 (4): $355-60$

Ochyra, R. \& Bednarek-Ochyra, H. 2011. Schistidium deguchianum (Grimmiaceae), a new Andean species from Peru. Journal of Bryology, 33(3): 189-94.

Ochyra, R. \& Bednarek-Ochyra, H. 2013. On the identity of Ditrichum validinervium (Bryophyta, Ditrichaceae). Cryptogamie, Bryologie, 34(3): 299-306.

Ochyra, R. \& Bednarek-Ochyra, H. 2014. Dicranella hookeri (Dicranaceae, Bryophyta) in northern Argentina. Telopea, 17: $331-5$.

Ochyra, R. \& Bednarek-Ochyra, H. 2015a. Dicranoweisia fastigiata, a new synonym of Hymenoloma antarcticum (Seligeriaceae). Cryptogamie, Bryologie, 36: 41-5.

Ochyra, R. \& Bednarek-Ochyra, H. 2015b. The earliest recognition of Schistidium occidentale (Grimmiaceae, Bryophyta), with a review of species of Schistidium subg. Canalicularia. Arctoa, 24: $32-6$

Ochyra, R. \& Bell, B.G. 1984. A record of Schistidium falcatum (Bryophyta: Musci) from the Antarctic. British Antarctic Survey Bulletin, 64: 77-9.

Ochyra, R. \& Hertel, H. 1990. Contribution to the moss flora of the subantarctic island Marion. Polish Botanical Studies, 1: $19-34$.

Ochyra, R. \& Lewis Smith, R.I. 1998. Antarctic species in the genus Ditrichum (Ditrichaceae, Bryopsida), with a description of D. gemmiferum sp. nov. Annales Botanici Fennici, 35: 33-53

Ochyra, R. \& Newton, M.E. 1985. The taxonomy and distribution of Dicranella cardotii (R. Br. ter.) Dix., an addition to the moss flora of Antarctica. Lindbergia, 11: 94-8.

Ochyra, R. \& Singh, S.M. 2008. Three remarkable moss records from Dronning Maud Land, continental Antarctica. Nova Hedwigia, 86: 497-506.

Ochyra, R. \& van Rooy, J. 2013. Distribution of Bucklandiella lamprocarpa (Grimmiaceae, Musci) in South Africa. Cryptogamie, Bryologie, 34(3): 359-66.

Ochyra, R., Sérgio, C. \& Schumacker, R. 1988. Racomitrium lamprocarpum (C. Muell.) Jaeg., an austral moss disjunct in Portugal, with taxonomic and phytogeographic notes. Bulletin du Jardin botanique national de Belgique/Bulletin van de National Plantentuin van België, 58: 225-58.

Ochyra, R., Szmajda, P. \& Bednarek-Ochyra, H. 1992. M. 396. Bartramia pomiformis Hedw. In: R. Ochyra \& P. Szmajda, eds. Atlas of the geographical distribution of spore plants in Poland. Series V. Mosses (Musci). 8. Kraków: W. Szafer Institute of Botany, and Poznań: Adam Mickiewicz University, pp. 41-50+1 map. (In English and Polish).

Ochyra, R., Kempa, R. \& Buck, W.R. 2000. Plagiothecium lucidum (Hook. f. \& Wils.) Paris in tropical Africa. Tropical Bryology, 18: $147-52$

Ochyra, R., Bednarek-Ochyra, H. \& Lewis Smith, R.I. 2002. New and rare moss species from subantarctic South Georgia. Nova Hedwigia, 74(1-2): 121-47.

Ochyra, R., Bednarek-Ochyra, H. \& Lewis Smith, R.I. 2008a. New and rare moss species from the Antarctic. Nova Hedwigia, 87 (3-4): 457-77.

Ochyra, R., Lewis Smith, R.I. \& Bednarek-Ochyra, H. 2008b.The illustrated moss flora of Antarctica. Cambridge: Cambridge University Press

Ochyra, R., Bednarek-Ochyra, H. \& van Rooy, J. 2013. Dicranella hookeri (Dicranaceae, Musci), an addition to the moss flora of continental Africa. Herzogia, 26: 169-74.

Ochyra, R., Váňa, J., Smith, V.R. \& Cykowska-Marzencka, B. 2014a. Seven liverwort species new or confirmed from subantarctic Prince Edward Island. Herzogia, 27: 397-407.

Ochyra, R., Zander, R.H. \& Lebouvier, M. 2014b. Antipodal mosses: XVIII. Syntrichia christophei, a new species from subantarctic Iles Kerguelen. Cryptogamie, Bryologie, 35(1): $37-46$. 
Ochyra, R., Crabtree, D. \& Tangney, R. 2015. Studies on mosses in the Falkland Islands: I. Bucklandiella and Codriophorus (Grimmiaceae). Cryptogamie, Bryologie, 36(3): 289-310.

Oliván, G., Fuertes Lasala, E. \& Acon, M. 2007. Hygrohypnum (Amblystegiaceae, Bryopsida) in the Iberian Peninsula Cryptogamie, Bryologie, 28(2): 109-43.

Olsson, S., Buchbender, V., Enroth, J., Hedenäs, L., Huttunen, S. \& Quandt, D. 2010. Phylogenetic relationships in the "Pinnatella"clade of the moss family Neckeraceae. Organisms Diversity \& Evolution, 10: 107-122.

Olsson, S., Enroth, J., Huttunen, S. \& Quandt, D. 2016. Phylogeny of Neckeropsis and Himantocladium (Neckeraceae, Bryophytina). Bryophyte Diversity \& Evolution, 38(2), 53-70.

O'Shea, B.J. 2006. Checklist of the mosses of sub-Saharan Africa (version 5, 12/06). Tropical Bryology Research Reports, 6: 1-252. Available at: http://www.nhm.ac.uk/hosted_sites/ bbstbg/resources lit africa.html

Papp, B., Erzberger, P., Ódor, P., Hock, Z.S., Szövényi, P., Szurdoki E. \& Tóth, Z. 2010. Updated checklist and red list of Hungarian Bryophytes. Studia Botanica Hungarica, 41: 31-59.

Peralta, D.F. 2015. Bryaceae in Lista de Espécies da flora do Brasil Jardim Botânico do Rio de Janeiro [online]. [accessed 18 November 2017]. Available at: http://floradobrasil.jbrj.gov. br/jabot/floradobrasil/FB96021.

Poponessi, S., Aleffi, M., Gigante, D., Venanzoni, R. 2016. Updates on the bryophyte flora of the lowland woods and temporary ponds west of Lake Trasimeno (Central Italy). Flora Mediterranea, 26: 151-62.

Redfearn, P.L. Jr. \& Wu, P.-C. 1986. Catalog of the mosses of China. Annals of the Missouri Botanical Garden, 73: 177-208.

Regulation of the Minister of the Environment. 2014. Dated 9 October 2014 on the protection of plant species. Journal of Laws 2014, Item 1409.

Ros, R.M., Cano, M.J. \& Guerra, J. 1999. Bryophyte checklist of northern Africa. Journal of Bryology, 21(3): 207-44.

Ros, R.M., Mazimpaka, V., Abou-Salama, U., Aleffi, M., Blockeel, T.L., Brugués, M., Cros, R.M., Dia, M.G., Dirkse, G.M. Draper, I. El, Saadawi, W., Erdağ, A., Ganeva, A., Gabriel, R., González-Mancebo, J.M., Granger, C., Herrnstadt, I., Hugonnot, V., Khalil, K., Kürschner, H., Losada-Lima, A. Luís, L., Mifsud, S., Privitera, M., Puglisi, M., Sabovljevíc, M., Sérgio, C., Shabbara, H.M., Sim-Sim, M., Sotiaux, A. Tacchi, R., Vanderpoorten, A. \& Werner, O. 2013. Mosses of the Mediterranean, an annotated checklist. Cryptogamie, Bryologie, 34 (2): 99-283.

Rothero, G. 2006. Bryophytes. In: P. Shaw \& D. Thompson, eds. The nature of the Cairngorms: diversity in a changing environment. Edinburgh: The Stationery Office, pp. 195-214.

Sawicki, J., Szczecińska, M., Bednarek-Ochyra, H. \& Ochyra, R. 2015. Mitochondrial phylogenomics supports segregates of Racomitrium (Bryophyta, Grimmiaceae). Nova Hedwigia, 100: 293-317.

Schnyder, N., Bergamini, A., Hofmann, H., Müller, N., SchubigerBossard, C., \& Urmi, E. 2004. Rote Liste der gefährdeten Moose der Schweiz. BUWAL-Reihe, Vollzug Umwelt. Bern: BUWAL, FUB \& NISM.

Schumacker R. \& Martiny P. 1995. Threatened bryophytes in Europe including Macronesia. In: Red data book of European bryophytes. Part 2: Threatened bryophytes in Europe including Macronesia. Trondheim: The European Committee for Conservation of Bryophytes, pp. 29-193.

Sérgio C., Figuera R. \& Menezes R. 2011. Modelling the distribution of Sematophyllum substrumulosum (Hampe) E.Britton as a signal of climatic changes in Europe. In Z. Tuba, N.G. Slack \& L.R. Stark, eds. Bryophyte ecology and climate change. Cambridge: Cambridge University Press, pp. 427-39.

Sharifnia, F., Cheraghi Nav, S., Salimpour, F. \& Akhoond Darzikolaei, S. 2012. Two new records from Hylocomiaceae for Iranian bryoflora. Journal of Plant Research, 6(4): 46-52.

Shaw, A. 1981. Pohlia andrewsii and $P$. tundrae, two new arcticalpine propaguliferous species from North America. Bryologist, 84: 65-74

Shevock, J.R., Ochyra, R. \& Buck, W.R. 2006. Observations on the ecology and distribution of Hydrocryphaea wardii, a southeast
Asian monospecific genus, reported new for China from Yunnan Province. Journal of the Hattori Botanical Laboratory, 100: 407-18.

Shevock, J.R., Ochyra, R., He, S. \& Long, D.G. 2011. Yunnanobryon, a new rheophytic moss genus from Southwest China. Bryologist, 114: 194-203.

Smith, A.J.E. 2004. The moss flora of Britain and Ireland. 2nd ed. Cambridge: Cambridge University Press.

Smith, G.L. 1971. A conspectus of the genera of Polytrichaceae. Memoirs of the New York Botanical Garden, 21(3): 1-83.

Smoczyk M. \& Wierzcholska S. 2008. Wyniki badań botanicznych jako podstawa do rozszerzenia sieci obszarów Natura $2000 \mathrm{w}$ zachodniej części Ziemi Kłodzkiej. In: M. Furmankiewicz \& B. Mastalska-Cetera, eds. Problemy wdrażania sieci Natura 2000 na obszarze Sudetów. Jelenia Góra: Muzeum Przyrodnicze w Jeleniej Górze, pp. 101-17. (In Polish).

Soldan, Z. 1992. Buxbaumia viridis. A candidate of "red lists" of bryophytes. Bryonora, 9: 40-4

Soukup, J. 1951. Algunas diatomeas del Peru y liste de los musgos peruanos. Boletin de la Sociedad Peruana de Botánica, 3: 67-78.

Staples, G.W., Imada, C.T., Hoe, W.J. \& Smith, C.W. 2004. A revised checklist of Hawaiian mosses. Tropical Bryology, 25: 35-69.

Ştefănuţ, S. 2008. The hornwort and liverwort atlas of Romania. Bucuresti: Ars Docendi, Universitatea din Bucuresti.

Ştefănuţ, S. \& Goia, I. 2012. Checklist and red list of bryophytes of Romania. Nova Hedwigia, 95: 59-104.

Streimann, H. \& Curnow, J. 1989. Catalogue of mosses of Australia and its external territories. Australian Flora and Fauna Series, 10: $\mathrm{i}-$ viii $+1-479$

Swiss bryophytes. 2017. Hygrohypnum styriacum (Limpr.) Broth. [accessed 17 October 2017]. Available at: http://www. swissbryophytes.ch/index.php/de/verbreitung?taxon id= nism-1559.

Touw, A. \& Ochyra, R. 1987. Additional notes on Neckeropsis 2. Lindbergia, 13: 97-104.

Tropicos. 2017. Tropicos Home - Missouri Botanical Garden. [accessed 23 October 2017]. Available at: http://www.tropicos. org/. (http://tropicos.org/Name/35108242?tab=distribution)

Vajda, L. 1966. Die Moosflora des Börzsöny-Gebirges. Fragmenta Botanica Musei Historico-Naturalis Hungarici, 4: 79-100.

Van der Putten, N., Stieperaere, H., Verbruggen, C. \& Ochyra, R. 2004. Holocene palaeoecology and climate history of South Georgia (sub-Antarctica) based on a macrofossil record of bryophytes and seeds. Holocene, 14: 382-92.

Van der Putten, N., Verbruggen, C., Ochyra, R., Spassov, S., de Beaulieu, J.-L., De Dapper, M., Hus, J. \& Thouveny, N. 2009. Peat bank growth, Holocene palaeoecology and climate history of South Georgia (sub-Antarctica), based on a botanical macrofossil record. Quaternary Science Reviews, 28: 65-79.

Van der Putten, N., Verbruggen, C., Ochyra, R., Verleyen, E. \& Frenot, Y. 2010. Subantarctic flowering plants: Pre-glacial survivors or post-glacial immigrants? Journal of Biogeography, 37: $582-92$.

Váňa, J., Lebouvier, M., Ochyra, R., Bednarek-Ochyra, H. \& Cykowska, B. 2010. Two noteworthy records of hepatics from Ile Amsterdam in the South Indian Ocean. Nova Hedwigia, Beiheft, 138: 229-39.

Váňa, J., Ochyra, R., Lebouvier, M. \& Cykowska-Marzencka, B. 2014. Bryophytes of Île Amsterdam in the South Indian Ocean: 1. Liverworts. Cryptogamie, Bryologie, 35(4): $335-71$.

Vanderpoorten, A. \& Goffinet, B., 2009. Introduction to bryophyte biology. Cambridge: Cambridge University Press, pp. 1-15.

Venturi, G. 1883. Une nouvelle espèces de Fissidens. Revue Bryologique et Lichénologique, 10: 93-4.

Wu, P. 2011. Neckeraceae. In: P. Wu \& M.R. Crosby, eds. Moss flora of China, English Version, Vol. 5. Erpodiaceae-Climaciaceae. Beijing: Science Press \& St. Louis: Missouri Botanical Garden Press, pp. 319-68.

Zander, R.H. 1993. Genera of the Pottiaceae: mosses of harsh environments. Bulletin of the Buffalo Society of Natural Sciences, 32: 1-378. 